\title{
Tolomeo y Copérnico en el Nuevo Mundo Juan O'Gorman y el muro sur de la Biblioteca Central en Ciudad Universitaria
}

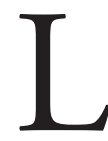

A astronomía como motivo visual llamó la atención de algunos artistas mexicanos como Rufino Tamayo, Frida Kahlo, Antonio Ruiz y Juan O'Gorman. Los cuatro realizaron pinturas y murales con el tema de los astros y pareciera que en algunas de esas imágenes intentaron transitar entre los límites del nacionalismo icónico, al tiempo que abrieron el debate sobre las nociones de lo local y la relación inversa con el espacio sin fronteras. Casi todas esas obras fueron pintadas en la década de los años cuarenta y principios de los cincuenta — quizá bajo el impacto de la segunda guerra mundial y el conflicto posbélico que habían enlazado al mundo en un destino común enunciado como el miedo a las explosiones atómicas y la sensación de que el planeta ya no era un conjunto de parcelas, sino una sucesión de interconexiones patentes en la política y en el ascenso de nuevas ramas de la tecnología y la ciencia. Esto pudo haber despertado la necesidad de explorar temas propios de la física y de reflexionar sobre el modo de lograr en imágenes una síntesis simbólica de nuevas verdades sobre el universo y la fisonomía de los astros.

En México, la astronomía contaba en esos años de guerra y posguerra con un moderno observatorio para hacer nuevas investigaciones, incitadas por el acceso a nuevos telescopios y cámaras. ${ }^{\mathrm{I}}$ La conciencia respecto de los nuevos

I. Luis Enrique Erro, "Las ideas básicas de la astronomía moderna", Cuadernos Americanos, ańo IX, vol. 5I, núm. 3, mayo-junio de 1950, pp. 85-104. 
modos de observación y el cambio de paradigma en la forma del espacio es patente en algunas obras de Tamayo, mientras que para Kahlo los astros, particularmente el enorme Sol insertado en su mural Moisés y el monoteísmo (1945), parecen provenir de imágenes telescópicas modernas.

Ruiz y O’Gorman se interesaron por el paso previo, es decir, por la adopción de una iconografía proveniente de los mapas cosmográficos que presentan en imágenes de intención comparativa las teorías de Tolomeo y Copérnico o dos círculos antagónicos: uno con la Tierra en el centro y el otro regido por el Sol, descentrando antiguas tesis sobre el movimiento de los astros, las cuales, sin embargo, perduraron en algunas instancias hasta mediados del siglo XIX.

Lo curioso es que el antiguo temor a un universo descentrado e infinito ha vuelto, hacia finales del siglo $\mathrm{xx}$, a ser objeto de un debate proveniente no de la religión sino de la reflexión filosófica contemporánea; ésta se ha manifestado en la discusión sobre las imágenes en las que lo circular, como forma, es un modo de ubicación y contención, mientras la llamada grandeza excesiva a la cual se refería Goethe ${ }^{2}$ pareciera causar inquietud, más aún cuando sabemos que la forma del universo es informe como la espuma.

Este trabajo está dedicado a la reflexión sobre la visualidad, las ideas y las fuentes iconográficas del muro sur de la Biblioteca Central de Ciudad Universitaria, realizado por Juan O'Gorman como parte de un proyecto mural que aspiraba a ser representativo de la historia de México desde los tiempos prehispánicos hasta la modernidad (el mural lleva por nombre Representación histórica de la cultura). El gran proyecto se realizó en mosaico, técnica con una materialidad más espesa que la pintura al fresco y quizá más adecuada a la visualidad de los códices prehispánicos, que O’Gorman incluyó como motivo e inspiración central en los muros principales (fig. I). Además de ser un argumento más para la cuestión de la "integración plástica" del muralismo con las superficies arquitectónicas, sobre todo las exteriores — un asunto muy en boga por aquellos años (y del que no me ocuparé aquí).

El pintor y arquitecto tenía la intención de contribuir — desde las imágenes y su carga simbólica diseñadas para una biblioteca- a la discusión de las ideas filosóficas y científicas en los periodos históricos convencionales que rigen aún la representación de la nación mexicana. Debo añadir que el análisis de esta obra de O'Gorman ha sido puesto en tensión a lo largo del texto con un

2. Jean Clair, "De Humboldt a Hubble", en Cosmos, Barcelona, Centro de Cultura Contemporánea, I999, p. 4. 


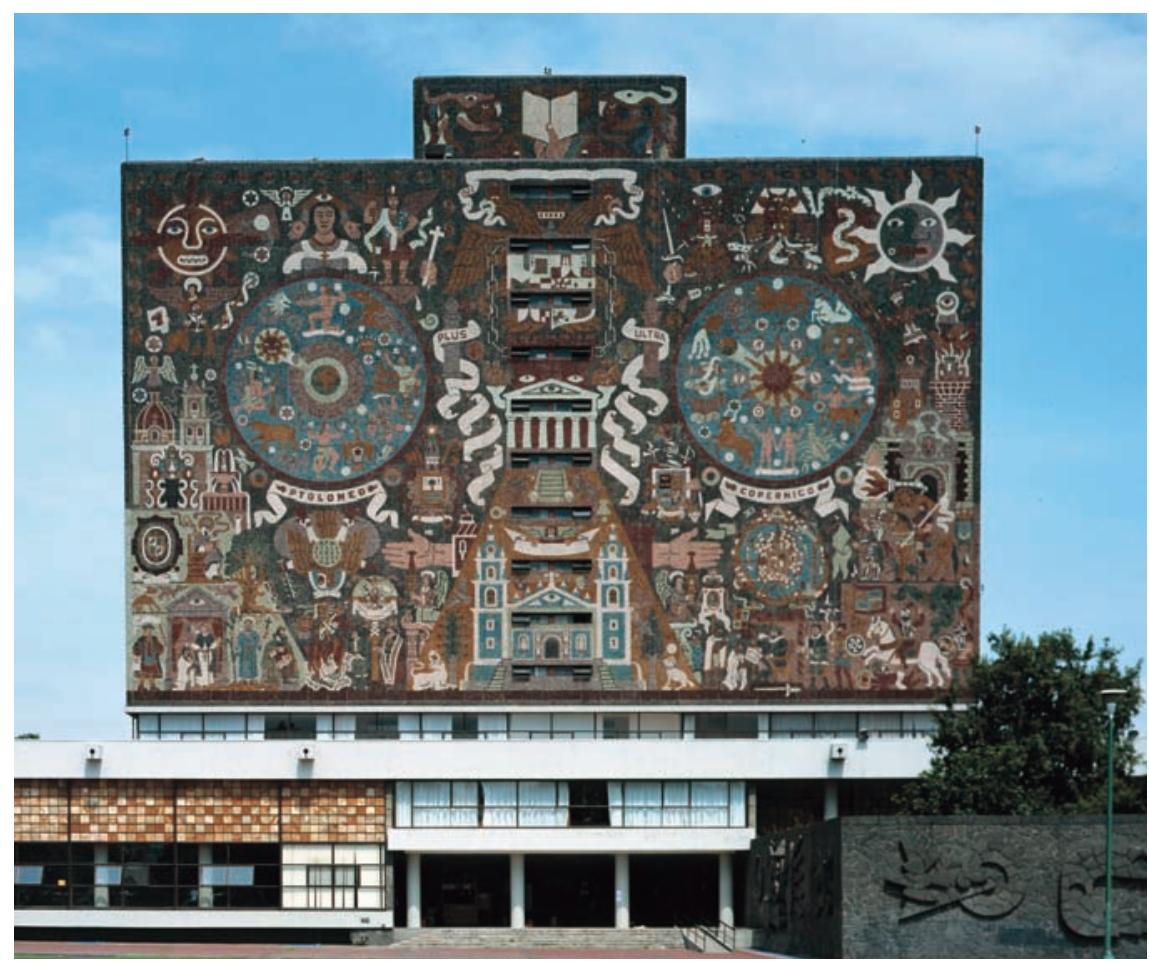

I. Juan O'Gorman, muro sur de la Biblioteca Central, Ciudad Universitaria, unam. Foto: Ernesto Peñaloza, 2003. Archivo Fotográfico Manuel Toussaint, ine-unam. "Reproducción autorizada por el Instituto Nacional de Bellas Artes y Literatura, 20I I". D.R. (J)uan O’Gorman/sOMAAP/MÉXICO/2OII.

mural pequeño, realizado por Antonio Ruiz en 1949, con un tema semejante y un objetivo distinto.

Tolomeo y Copérnico (tema del muro sur) —insertos en un programa iconográfico complejo- funcionan como emblemas del periodo virreinal y refieren - entre otras cosas - a la discusión sobre las teorías copernicanas en la Nueva España; un tema con muchas aristas que, lejos de explicarse sólo por la doctrina oficial de la Iglesia y su condena a Galileo, está relacionado con el proceso de modernidad gestado en el campo de la ciencia y otras disciplinas durante la época de la Colonia. El muro sur, por sus elementos visuales y temáticos, nos lleva a pensar de otra forma el debate astronómico durante el virreinato; el dilema entre ciencia y religión abre una rendija a la discusión 


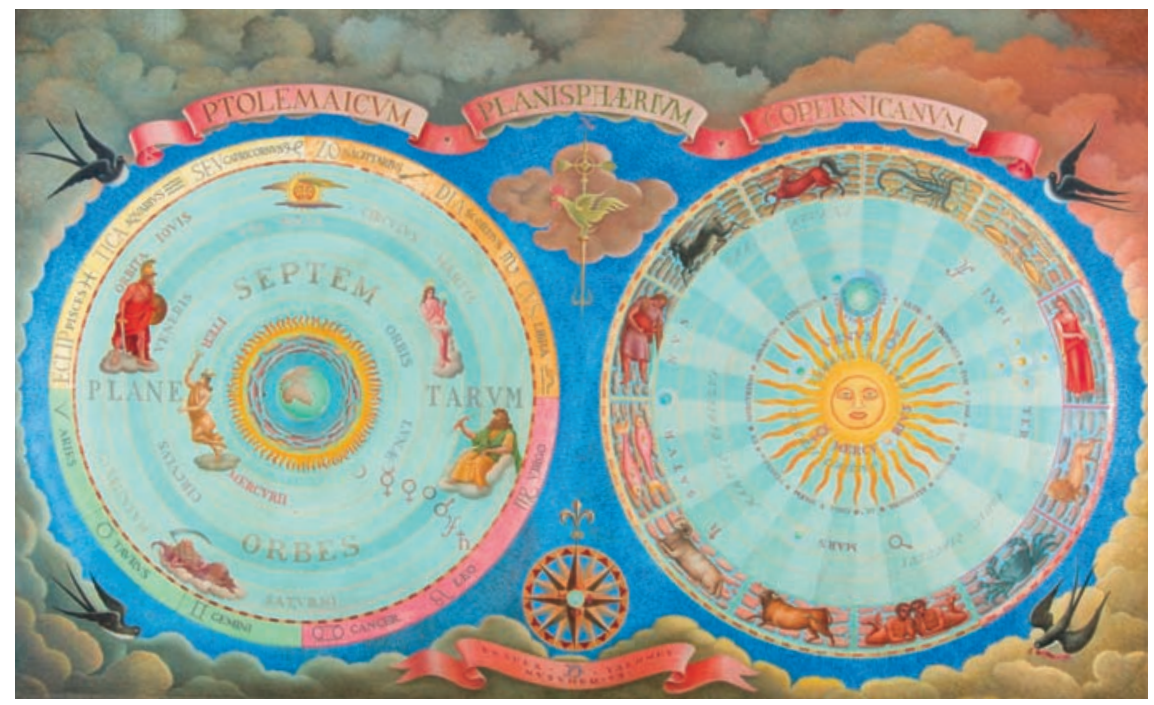

2. Antonio Ruiz, El Corcito, Planisphaerivm Ptolemaicvm et Copernicavm, I949. Foto:

Pedro Ángeles. Archivo Fotográfico Manuel Toussaint, ine-unam. Cortesía Luisa Barrios.

necesaria de los imaginarios producidos por el movimiento mexicano de pintura mural sobre esta época —impregnados en mayor o menor grado por la visión liberal de la historia, caracterizada en cierto sentido por la fabricación de estereotipos centrados alrededor de la Iglesia y eliminando aspectos como la educación y el conocimiento científico. ${ }^{3}$

Es muy probable que la idea de O'Gorman de presentar, por medio de un debate científico, la síntesis de una época que va de la Conquista (I52I) hasta los albores de la Independencia (I8Io) se origine en la obra de Antonio Ruiz de 1949, precisamente con el título de Planisphaerivm Ptolemaicvm et Copernicavm (fig. 2). El hecho de que existan dos obras realizadas muy cercanas

3. La doble significación del mural, patente en la composición ascendente — desde escenas de la Conquista hasta el debate que proviene de la ciencia-, podría aludir también a los distintos términos considerados quizá erróneamente asimilables para denominar la época: Colonia, época virreinal o periodo novohispano. Puede pensarse que las intenciones del pintor están rebasadas por lo cual llega a sugerir, por ejemplo, que en el mural pueden detectarse dos de estos conceptos: la Colonia y lo novohispano como diferenciados y entretejidos a la vez. Lo colonial se refiere a dominación mientras lo novohispano sería considerar la existencia de un proyecto distinto relacionado con la discusión sobre la ciencia y su contribución al movimiento de independencia de raíz criolla. 
en el tiempo con un mismo tema que puede calificarse de singular - por lo menos en el contexto de la historia de la pintura moderna mexicana— añade complejidad al análisis y plantea la pregunta de significados diferentes frente a motivos de un visible parecido. Por lo que hemos de desarrollar en adelante, pareciera que Ruiz, con este tema, hace referencia al doble papel desempeñado por los jesuitas en el campo astronómico. Si bien fueron descubridores de las primeras manchas del Sol y divulgaron la revolución copernicana, por otro lado, en los escritos de algunos jesuitas activos en México — que mostraban su conocimiento de las tesis del astrónomo polaco - terminaban por negarles validez posiblemente por presiones de la Iglesia. El mural de O'Gorman utiliza la oposición Tolomeo/Copérnico en forma alegórica por dos razones: una evidente que intenta un debate sobre el bien y el mal, y otra, menos inmediata, que se aleja del optimismo de la ciencia y pone en cuestión la mirada evolutiva del nacionalismo mexicano y del progreso de la humanidad en general.

\section{La Biblioteca Central}

La Biblioteca continúa siendo el paradigma de la construcción del saber tanto en términos materiales como simbólicos, la cual quizá pronto será sustituida por el almacenamiento digital; mientras tanto, subsiste y constituye aún un reto para la arquitectura contemporánea. ${ }^{4}$ Cuando Juan O'Gorman diseñó la Biblioteca Central en Ciudad Universitaria (cuya construcción se inició en I949 y concluyó en 1953), el artista se planteó una variedad de problemas conceptuales, entre ellos, cómo significar el conocimiento y cómo proyectar una narración en imágenes que convocara a la discusión de las ideas y al mismo tiempo fuese fiel a la empresa mural monumental. Esta fidelidad implicaba - dentro de la gran narrativa propia del moderno muralismo mexicanoencontrar aquellos aspectos emblemáticos capaces de alegorizar momentos clave del devenir cultural de México, algo (la voluntad de un gran relato continuo) que caracteriza aspectos ficcionales de una historia del arte nacional en México. Estos momentos de síntesis se elaboraron con frecuencia frente a la proble-

4. Algunos ejemplos son: Norman Foster, conocido por su capacidad de hacer adaptaciones de arquitectura contemporánea a edificios históricos, como, por ejemplo, las intervenciones en la British Library y en la New York Public Library, y Rem Koolhaas, quien realizó en 2004 la Seattle Public Library en los Estados Unidos. 
mática de la dicotomía entre indígenas y españoles y su distinta concepción de las imágenes. El plan de O'Gorman para la Biblioteca implicaba concebir el programa iconográfico, así como pensar la espacialidad, el sitio específico y la constitución simbólica del mural por medio de la forma, el color y la articulación de los conceptos en un tejido complicadísimo de piedras de color que creaban y recreaban las siluetas y las imágenes de varios códices (el borbónico, el mendocino y el Lienzo de Tlaxcala, entre otros) mezclados con símbolos y emblemas de la física moderna. Aunque O'Gorman fue crítico de su proyecto - por no haber logrado contribuir realmente a la mexicanidad en arquitectura (se recriminaba el uso del racionalismo internacionalista) —, creía haber concretado la propuesta de un arte propio en la decoración del edificio. Hay en su proyecto arquitectónico y decorativo una referencia simbólica indirecta a los amoxcalli o lugares destinados en la época prehispánica al almacenamiento de los códices. El diseńo de este edificio y su marcada horizontalidad pareciera hacer referencia a los modos de lectura del códice (planos horizontales) con un lenguaje pictográfico sobre una superficie rugosa.

Los otros problemas, de carácter técnico, incluían cómo hacer un mural de gran tamaño, a la intemperie, que resistiese los fenómenos ambientales: el arquitecto encontró la respuesta en el uso de piedras de color naturales cuya recolección lo llevó a diversos estados de la República — desde Guerrero hasta Zacatecas-, con el fin de obtener la diversidad de gamas necesarias para el monumental recubrimiento de dichos muros. Juan O'Gorman se inició en la técnica del mosaico al lado de Diego Rivera, en particular durante la construcción del Anahuacalli, que tomó 13 años después de iniciarse su proyección en 1944. Sin embargo, Juan ya estaba ampliamente familiarizado con las piedras de color que interesaron a su padre, el químico y pintor Cecil Crawford O'Gorman, con quien emprendió varios viajes con el propósito de encontrar la mayor variedad de estos materiales. Según el arquitecto, llegó a visitar una enorme cantidad de minas y canteras de las cuales obtuvo 150 piedras de diferentes colores, menos el azul que logró elaborar por medio de vidrios coloreados o cortados en lajas. 5 Es entendible su interés por el azul turquesa, color

5. Juan Coronel Rivera, "Piedra enredadera", en O’Gorman, México, Bital, 2003, p. 224; Antonio Luna Arroyo, Juan O'Gorman. Autobiografía, antología, juicios estéticos y documentación exhaustiva sobre su obra, México, Cuadernos Populares de Pintura Mexicana Moderna, I973, p. I 43. Los primeros murales en mosaico realizados por O’Gorman fueron hechos para el músico Conlon Nancarrow, cuya casa construyó. En los muros de los corredores y en varios sitios del jardín ejecutó esos murales. Siguieron los murales en mosaico de la Universidad 
emblemático de lo sagrado en el arte prehispánico y que utilizó en abundancia en los murales de Ciudad Universitaria.

La historia de la construcción de la Biblioteca y las relaciones arquitectónicas supuestamente fallidas con el estilo internacional, la contradicción entre función y decoración y el hecho de ser un ejemplo polémico de integración plástica son temas y debates conocidos y complementarios al tema que me propongo tratar con mayor detalle y que se concentra en el choque de dos culturas (españoles e indígenas) cuyas imágenes salen de los códices; el conflicto histórico se verá coronado en la parte superior y será más visible por dos grandes círculos que corresponden a concepciones cosmográficas opuestas y que el artista asocia a valores morales como el bien (geocentrismo) y el mal (heliocentrismo), tal como imaginó que fueron comprendidos durante la época del virreinato bajo la égida de la Iglesia católica.

Es evidente que para entrar en el tema del muro sur es indispensable entender, aunque sea parcialmente, el planteamiento del programa iconográfico total plasmado en el edificio de la Biblioteca. Éste puede estudiarse mejor en los dibujos del proyecto, ya que para captar todos los detalles habría que subirse a un andamio móvil y muy alto, indicio de que en tanto arte público comunicable hay algo fallido, lo cual el propio O'Gorman fue el primero en censurar o reconocer. El programa iconográfico está inscrito en cuatro muros que miran hacia los puntos cardinales y cada uno de los soportes señala un periodo histórico: el norte, la época prehispánica; el sur, el tiempo de la Colonia; el oriente recurre a la dualidad entre tradición y progreso encarnados en el campo y la ciudad, rodeada de emblemas prehispánicos y signos de la física moderna; el poniente está dedicado a la actividad universitaria y en él pueden verse motivos estudiantiles como el deporte. Hay evidencia de que O'Gorman, en el muro poniente, quiso colocar los símbolos de la física newtoniana y relativista como referencia al ingenio humano, pero según la versión oficial, Carlos Lazo, uno de los arquitectos a cargo del proyecto total, le pidió sustituirlo por el escudo universitario. ${ }^{6}$

El muro más llamativo es el orientado hacia el norte, fundamentado en la estética pictórica de algunos códices prehispánicos, particularmente el Borgia, y en el que destacan valores de representación como la planimetría. Para expre-

Nacional Autónoma de México y varios más para distintos lugares públicos. En general, se observa en los posteriores trabajos en mosaico en Ciudad Universitaria una tendencia más didáctica y con mucho menor carga simbólica y conceptual.

6. Miguel Ángel Bahena Pérez et al., Restauración del mural: representación histórica de la cultura de Juan O'Gorman, México, Universidad Nacional Autónoma de México, 1996. 
sar la referencia a otra tradición pictórica en este muro colocado a la entrada de la Biblioteca, quizá el artista encontró en el mosaico una forma de detener el flujo de la línea y lograr una mayor sensación de frontalidad.

El hecho de que estos murales estén constituidos desde el punto de vista material por partículas tiene consecuencias ópticas e introduce en la mirada la sensación de caos, lo cual añade una dicotomía más al mural. Las piedras de color tan diversas y pequeñas producen una interferencia en el campo de la percepción que cuestiona el esquema de totalidad a la cual aspiraba el arquitecto con esta obra monumental, compuesta de pedacería colorida.

El proceso visual e imaginario que precipita esta obra —en parte por cierto hieratismo impuesto por el material que detiene la mirada y por la enorme riqueza de formas, símbolos y figuras - puede definirse como un almacén de memorias y datos, de claves que obligan al juego del lince y al ejercicio de la comprensión de lo simbólico como el lugar de la sustitución y de la invención de lenguajes no textuales que funcionan como indicadores de nociones cambiantes de espacio y tiempo o, por el contrario, de su retardo. El deseo de una percepción visual ampliada implícita en el proyecto decorativo de la Biblioteca convoca a una vasta acumulación de reflexiones sobre la percepción y experiencias cognitivas simultáneas. Los miles de pequeñas piedras de colores rellenan las siluetas y dan forma a narrativas de complejidad simbólica que se deslizan por un plano rugoso, entreteniendo los ojos que en vano intentan captar desde lejos el detalle. La forma geométrica de la arquitectura de raíz funcionalista pierde algo de su simetría y desde luego de su pretendida pureza al verse revestida de una gruesa textura pétrea y asimétrica dominada por el color verde azulado, interferida por rojos, rosas, negros, amarillos y otras tonalidades. En cierto sentido, la comunicabilidad a la cual aspiraba el arte público desde los muros, en este caso, se niega al espectador que intenta captar el todo y el detalle.

La Biblioteca Central, por su ubicación espacial, color y complejidad sígnica, es el edificio moderno más difundido, por medio de la fotografía, del México moderno. Las tensiones de la imagen (parte de su atractivo) proceden de su eclecticismo o de tomar dos tradiciones opuestas que chocan y se complementan y producen una forma alternativa de entender visual y culturalmente las imágenes. Como ya se apuntó, destacan la planaridad en el muro norte y la introducción de la perspectiva en el muro sur fundamentado en la estética de un códice colonial en particular (el Lienzo de Tlaxcala), imbuido de forma y espacialidad occidentales. O'Gorman proyecta en esta obra el encuentro de distintas y opuestas maneras de hacer frente a las imágenes que logra ilumi- 
DOI: http://dx.doi.org/10.22201/iie.18703062e.2011.98.2364

TOLOMEO Y COPÉRNICO EN EL NUEVO MUNDO

nar y diferenciar por medio de las cualidades colorísticas y luminosas de los componentes pétreos que abrazan en forma total el edificio.

\section{Ciencia y religión}

El tema y el motivo más inmediato y aparente del muro sur, la polémica entre heliocentrismo y geocentrismo, no eran desconocidos en México en tiempos de la formación de la nación moderna, la cual cristaliza con lo que se conoce como la República restaurada; un ejemplo es la pintura de Félix Parra, Galileo en la Universidad de Padua demostrando las nuevas teorías astronómicas (I873, I66.9 × I84.5 cm). Según la descripción de Fausto Ramírez, ${ }^{7}$ el cuadro presenta al hombre de ciencia con un compás que se desliza sobre un globo celeste el cual descansa sobre una mesilla. Frente a él, un fraile franciscano. El significado de la imagen se vuelve transparente por medio de los libros sobre los cuales el fraile posa las manos y otros más que se encuentran en el estante enmarcando la figura de Galileo; son los libros del debate entre ciencia y religión de autores como Tolomeo, Aristóteles y Platón, una Biblia y el De revolutionibus de Copérnico:

A la derecha detrás del fraile, sobre otra mesa, está un volumen de las obras de san Agustín, cubriendo parcialmente un pliego donde se ve un orbe surcado de cráteres y protuberancias, testimonio de las observaciones de la superficie de la Luna efectuadas mediante el anteojo o telescopio por Galileo. Esta obra es un indicio de que el astrónomo italiano se convirtió en una figura emblemática del enfrentamiento entre la fe y el conocimiento. Aquí dio forma pictórica al enfrentamiento ideológico entre los partidarios de la sistematización científica avalada por la observación y el experimento y los que apoyaban sus teorías en la autoridad libresca. ${ }^{8}$

Sin embargo, a pesar de algunos ejemplos pictóricos del debate cosmográfico moderno en la pintura mexicana, el antecedente iconográfico y desde luego formal del muro sur es la ya mencionada obra de Antonio Ruiz — pintada por encargo de Valente Souza, compañero de estudios de Ruiz al igual que el astró-

7. Fausto Ramírez, "Galileo en la Universidad de Padua demostrando las nuevas teorías astronómicas”, en Catálogo comentado del acervo del Museo Nacional de Arte. Pintura, siglo XIX, México, Consejo Nacional para la Cultura y las Artes-Instituto Nacional de Bellas ArtesMuseo Nacional de Arte, 2004, t. II, pp. I52-I57.

8. Idem. 
nomo Luis Enrique Erro, aficionado a los telescopios y la observación de los astros. ${ }^{9}$ Esta obra fue comisionada como mural para ser colocado a la entrada de un edifico propiedad de Souza. Al año siguiente, O'Gorman, un buen amigo y admirador de El Corcito (apodo conocido de Antonio Ruiz), ${ }^{\mathrm{IO}}$ se encontraba en plena actividad constructiva de la Biblioteca Central que incluye una superficie equivalente a io pisos. En la fachada sur de este edificio — de 43 metros de ancho por 27 de alto-, O'Gorman ideó algo diferente. Lo distinto estribó, sin decirlo abiertamente, en separarse del modelo ideológico que Diego Rivera solía emplear en sus murales con tema histórico. ${ }^{\text {II }}$ En ellos, Rivera favorecía los aspectos más estereotipados de la Conquista, empeñada — por medio de la guerra y la religión — en la destrucción de las antiguas culturas indígenas. O'Gorman se propone, en sus propias palabras, una serie de murales menos didácticos y más adecuados a la discusión de las ideas entre académicos:

Para hacer el mural de la época colonial consulté todos los documentos referentes a la concepción del universo de Tolomeo y Copérnico, que representé mediante dos grandes círculos, que significan dos posiciones axiológicas antagónicas. Tolomeo afirmó que la Tierra es el centro del universo — concepción bíblica— alrededor de la cual giran los astros, y que el hombre es el ser más importante de la creación. Copérnico, muchos años después, niega los principios de Tolomeo y declara que

9. Datos proporcionados por Pedro Friedeberg (marzo de 2009), quien conoció a Valente Souza a través de su hijo Antonio, dueño de una de las más prestigiadas galerías de arte en los años sesenta.

Io. Juan O'Gorman comentó en numerosas ocasiones — después y antes de la muerte de Antonio Ruiz en 1964- cuánto debía a su buen amigo, quien le enseñó a pintar al temple y a preparar los colores, entre otras técnicas. Según Alejandro von Waberer O’Gorman, sobrino del pintor: "Dentro de su formación pictórica un hecho de enorme importancia fue haber conocido al Corcito, que fue la persona más significativa en la orientación de Juan hacia el temple porque fue ni más ni menos el Corcito quien le enseñó a pintar con esta técnica. Desde entonces él estudió exhaustivamente a los grandes maestros italianos para llegar a la perfección de la pintura al temple. Y también a partir de ese momento nunca volvió a tocar el óleo, porque le parecía pastoso, vulgar. Él pintaba al temple porque entre otras virtudes que encontraba en esa técnica, le permitía dotar de una transparencia increíble a los colores". Citado en Roberto Vallarino, "Evocación de O’Gorman. Semblanza en cinco tiempos”, en O’Gorman, México, Bital, I999, p. 92.

II. Su fervor descriptivo y preferencia temática se acerca a la obra de Rivera sobre todo en su idea de la historia, que sigue de cerca la visión liberal de una antigüedad gloriosa, una conquista destructora, la constitución de la República y el triunfo de los liberales. Luego, un porfirismo abyecto y la liberación que significó la Revolución y las posibilidades de utopía. 
la Tierra es un satélite de una constelación particular que gira alrededor del Sol: al negarle a la Tierra el papel central del universo fue considerado como principio del mal dentro de la ideología religiosa. Fue entonces cuando pensé que era importante representar los conceptos cosmogónicos de la cultura de Occidente: el bien a través de Tolomeo y el mal con Copérnico. ${ }^{\mathrm{I} 2}$

En una segunda entrevista en $1978,{ }^{13}$ O'Gorman definiría nuevamente la temática general, y sobre el muro sur diría:

Me pregunté qué significaba fundamentalmente la época colonial ¿qué trajeron a México los españoles? Pues trajeron la cruz y el cristianismo basado en el principio del bien y el mal, pero ¿cómo representar esto cosmogónicamente? Se me ocurrió que la representación del universo por Tolomeo, con la Tierra en el centro, podía representar el bien, y la idea de Copérnico con la Tierra desplazada del centro, el mal; es decir, el bien, la fe, el mal, la ciencia. Con estos dos conceptos, el primero basado en la fe y el segundo en la ciencia, se representó básicamente la cosmología que los españoles trajeron a México. Puse también allí la cruz y la espada, los escudos de Carlos Vy de Felipe II, el Non plus ultra [sic], lema del reinado de Carlos V y de la época de la Conquista. En la parte baja y como símbolos del bien y del mal volví a hacer un friso con los personajes que representan sacerdotes, la quema de códices, la caída del águila, Cuauhtémoc, etc. Hay además otros símbolos, como son una pirámide sobre cuya base se instituye la Iglesia católica, las manos de Cristo chorreando sangre por las llagas, que es recogida en unas copas por los ángeles; éstas son las ideas fundamentales de la época colonial. ${ }^{14}$

Veinticinco años después definiría el efecto decorativo de los muros de la Biblioteca Central como el de un códice que se despliega por las paredes; así, fueron las cualidades estructurales en cuanto objetos y el sentido simbólico de los diversos códices los factores determinantes en el proyecto total. ${ }^{15}$ Sin embargo, no fue muy específico sobre las fuentes.

I2. Olga Sáenz, "Entrevista”, en Ida Rodríguez Prampolini et al. (eds.), La palabra de Juan O’Gorman, México, Universidad Nacional Autónoma de México-Instituto de Investigaciones Estéticas, 1983, p. 26.

I3. José Ortiz Monasterio, “Entrevista con Juan O’Gorman”, en Rodríguez, op. cit., p. 296.

14. Ibidem, pp. 296-297.

15. José Ortiz Monasterio, "Los murales de la biblioteca de cu se hicieron para evitar que el edificio fuera un monstruo", en op. cit., p. 295. 


\section{El Lienzo de Tlaxcala}

Una primera aproximación al Lienzo de Tlaxcala evidencia que fue ese códice (el más occidental de todos), el cual sirvió a O'Gorman a veces de modelo y otras de inspiración para realizar la parte baja del muro sur un tanto sometida al tamaño y la presencia de los círculos astronómicos, el que el espectador puede ver en forma más inmediata. Su cercana consulta de dicha fuente le permitió concretar su aspiración de una propuesta pictórica que diera cuenta en imágenes del encuentro de culturas diversas. Como bien se sabe, el original de este códice se encuentra perdido; sin embargo, existen varias copias y numerosas ediciones; quizá la que O'Gorman consultó en su tiempo fue la edición de Alfredo Chavero de I892. ${ }^{16}$

Según este erudito y coleccionista, el Lienzo de Tlaxcala es un documento jeroglífico de gran importancia, pues representa los principales sucesos de la Conquista pintados por los mismos indios en 86 cuadros realizados entre I550 y I564. Si bien este códice fue producto de manos indígenas, no es así en términos de tradición visual, ya que la figuración y el sentido del espacio en él están ligados al aprendizaje pictórico occidental.

El Lienzo de Tlaxcala representa el punto de vista tlaxcalteca de la conquista de Tenochtitlan y posteriores batallas y expediciones. Fue comisionado y pintado en la época del virrey Luis de Velasco, según Chavero, para documentar la lealtad de los tlaxcaltecas a la Corona e interceder por ellos.

$\mathrm{Si}$ leemos el mural de abajo hacia arriba, encontraremos que las figuras de los españoles a caballo, en particular las de Cortés y Pedro de Alvarado, proceden directamente del Lienzo. También Cortés, ya no como soldado sino como autoridad simbolizada en la figura sentada en una silla de cadera por obra y gracia de Carlos V, pertenece al mismo códice, así como el despliegue de las diversas figuras de los tlaxcaltecas que llevaron a Cortés hacia Tenochtitlan. La parte central que, en una primera apreciación, resulta enigmática es — como muestra la comparación visual — una apropiación de la imagen de dicho códice, la cual es la más alegórica al colocar en el centro el escudo de Carlos V y, bajo éste, las dos columnas emblemáticas de su reino y su lema Plus ultra. ${ }^{17}$

I6. Publicado por Alfredo Chavero en México, I892; véase también "La conquista de México, Lienzo de Tlaxcala”, Artes de México, año XI, núms. 5 I y 52, 1964, Miguel Salas Anzures, director; y Mario de la Torre (ed.), Lienzo de Tlaxcala, México, Cartón y Papel de México, 1983, edición de la cual se tomaron las fotografías que ilustran este texto.

17. Plus ultra (del latín "más allá") es el lema nacional de España utilizado por primera vez 
DOI: http://dx.doi.org/10.22201/iie.18703062e.2011.98.2364

TOLOMEO Y COPÉRNICO EN EL NUEVO MUNDO
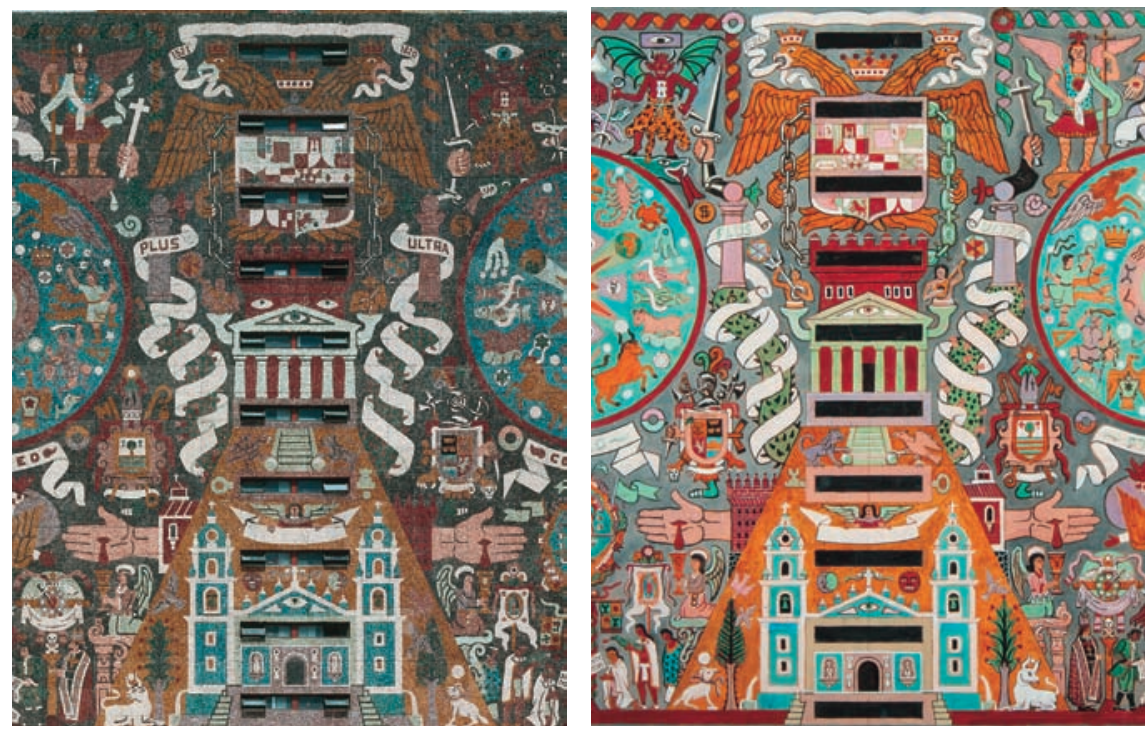

3a) Detalle del muro sur de la Biblioteca

Central. Foto: Ernesto Peńaloza, 2003; b) Juan O'Gorman, detalle del boceto del muro sur de la Biblioteca Central. Palacio de la Autonomía. Foto: Columba Sánchez y Gerardo Vázquez; y c) detalle del Lienzo de Tlaxcala, "Representa los diversos gobiernos habidos, ya en la colonia, hasta la época de D. Luis de Velasco", lám. 68.

Biblioteca Nacional, unam. Foto: Pedro Ángeles (supra. n. I6).

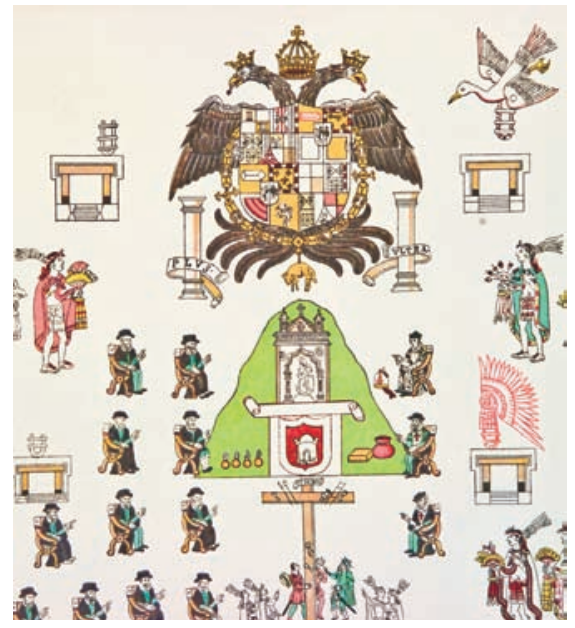


Hacia el límite inferior del mural, el pintor modificó el esquema del códice al sobreponer a la pirámide o tépetl, signo de fundación territorial, dos templos cristianos con elementos constructivos clásicos. Más abajo, la cruz que será sustituida por las manos estigmatizadas y sangrantes de un Cristo con cierto aire prehispánico, clara alusión al mestizaje o fusión étnica y cultural, marcado por la violencia (véanse figs. 3a-c).

\section{Los ojos y sus relaciones con el bien y el mal}

El muro sur, en tanto despliegue de imágenes, combina en forma original dos tradiciones de registro visual diferentes: el mapa y el códice, los cuales refieren a disciplinas y narraciones distintas, como la cosmografía y la historia utilizadas en contextos diferentes que convocan a variados estratos y problemáticas de la época colonial. Podría decirse que como imagen es compuesta e híbrida, $y$, sin embargo, logra cierta unificación visual mostrando la viabilidad de un sincretismo crítico. En esta síntesis destacan los detalles, y entre ellos lo más llamativo son los ojos que aparecen en distintas formas (figs. 4a-c): del lado izquierdo del espectador — es decir, del ala tolemaica o del bien-, aparecen en los pedimentos de los templos dibujados al centro como los ojos de Dios y en el pequeño templete donde se lleva a cabo el bautismo, mientras que del lado derecho del muro, dedicado a Copérnico, están colocados en la cresta de los diablos y en los astros. En el Lienzo de Tlaxcala, que O'Gorman implicó en este mural, hay varias escenas de guerra y derrota infligida por los españoles a los indígenas, como la batalla de Xalixco (figs. 4 b y $6 \mathrm{c}$ ), donde bien puede verse del lado derecho superior de la escena un gran ojo llorando ante el escenario de la batalla perdida, mientras que el Sol aparece en otras láminas en la misma ubicación del ojo si hay triunfo para los indígenas (fig. 5c). Ésta es una discrepancia de interés si se parte de la idea de que el códice fue comisionado para celebrar y conmemorar la participación de los tlaxcaltecas en el proceso de la Conquista que, si bien unidos a los espańoles, pareciera contener una dualidad por la inserción de la simbología del ojo llorando (figs. 4b y 6c) y el

por Carlos V. El lema proviene del humanista milanés y consejero del rey Luigi Marliano y se utilizó para desafiar el mito de las columnas de Hércules, límite del mundo (Non terrea plus ultra) y última frontera para los navegantes en el estrecho de Gibraltar. Plus ultra está estrechamente ligado a las conquistas que lograron los viajes de navegación en tierras americanas. 

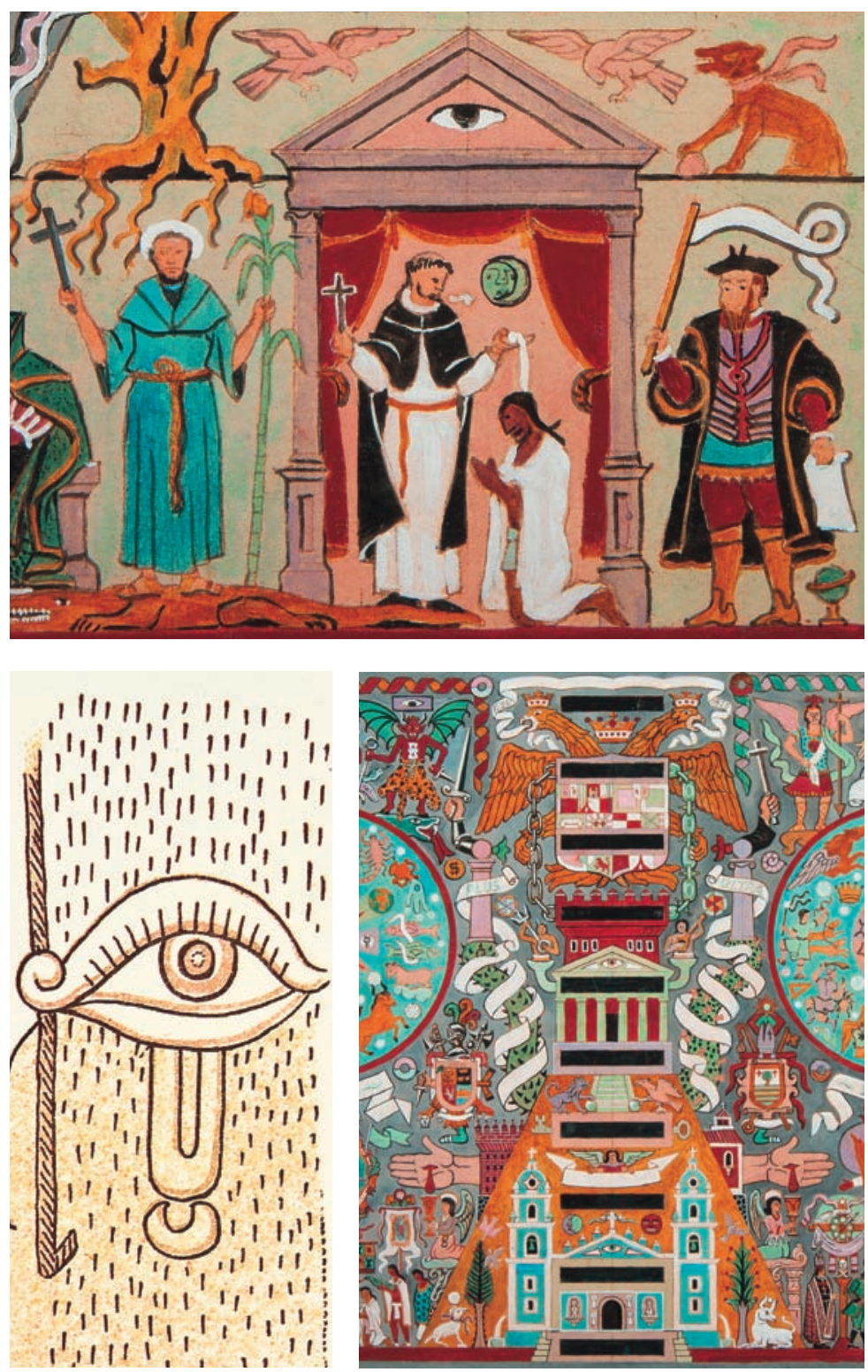

4a y c) Detalles del boceto del muro sur de la Biblioteca Central. Fotos: Columba Sánchez y Gerardo Vázquez. Archivo Fotográfico Manuel Toussaint, IIE-UnAm; b) detalle de la batalla de Xalixco, Lienzo de Tlaxcala, lám. 53. Biblioteca Nacional, unam. Foto: Pedro Ángeles (supra. n. I6). 
signo del Sol que celebra las victorias indígenas (fig. 5c). Quizá fue esta dicotomía de una lealtad ambigua lo que predispuso a O'Gorman a introducir en este muro sur juicios y verdades dislocadas sobre el bien y el mal (figs. 5a-d). La insistencia del arquitecto en el esquema dual, el bien y el mal, recurre a convenciones como encarnar el mal en el cuerpo del diablo que abraza el círculo copernicano y, sin embargo, llama la atención que algunos elementos, como la Ley de Indias — cuya grafía está invertida para añadir una desestabilización más en el significado-, pertenezcan a la parcela dedicada al mal en la medida en que el pintor parece parodiar la ortodoxia de las categorías opuestas. El bien asoma como una cabeza de ángel con cierto parecido a Malinche, quien aparece a los pies del mural en el contexto de una escena de la quema de códices que sin duda estaría asociada con el mal (figs. 6a y 6b). Pareciera una manera de cuestionar la normatividad de los valores, así como la dicotomía Tolomeo/Copérnico y lo contradictorio de su recepción en el campo científico y el de la fe.

En la Biblioteca de Alejandría, Tolomeo desarrolló su idea del geocentrismo; fue el primer centro de investigación que intentaba ser ecuménico, el lugar donde el astrónomo desarrolló su tratado, el Almagesto, y su geocentrismo, lo cual atrasó la concepción heliocéntrica durante más de I 500 años, mientras que otros geógrafos del tiempo de Tolomeo ya habían concebido el heliocentrismo, pero sus ideas no prosperaron. ${ }^{{ }^{8}}$ Así, un centro de investigación podía proteger, con la misma insistencia que las instituciones religiosas, creencias que atrasaran el desarrollo de la ciencia. El bien y el mal no son sólo una cuestión de valores religiosos: también aluden a los equívocos de la razón y de la sabiduría amparados en un marco institucional.

Los ojos que se encuentran en este mural tienen varias acepciones: por un lado, están ligados a los modos de expresión prehispánica y, por el otro, aluden a la observación y a la ciencia que están del lado del mal. El ojo representa el poder de la observación, ya sea el ojo omnipotente de Dios, la contemplación de los astros antes del telescopio y el lugar de la óptica en la creación de las imágenes. Son estos ojos los que también revelan varios factores en conflicto, como serían la fe y el poder interferidos por la ciencia, transforma-

I8. Basta recordar las ideas de la filósofa y astrónoma Hipatia, quien había llegado a la conclusión copernicana y que fue víctima de escarnio y lapidación en medio de conflictos religiosos de enorme envergadura. Así, una biblioteca y un gran centro de investigación y de enseñanza podrían dar cabida a ideas y teorías erróneas por su sujeción al poder y a los partidos religiosos. 

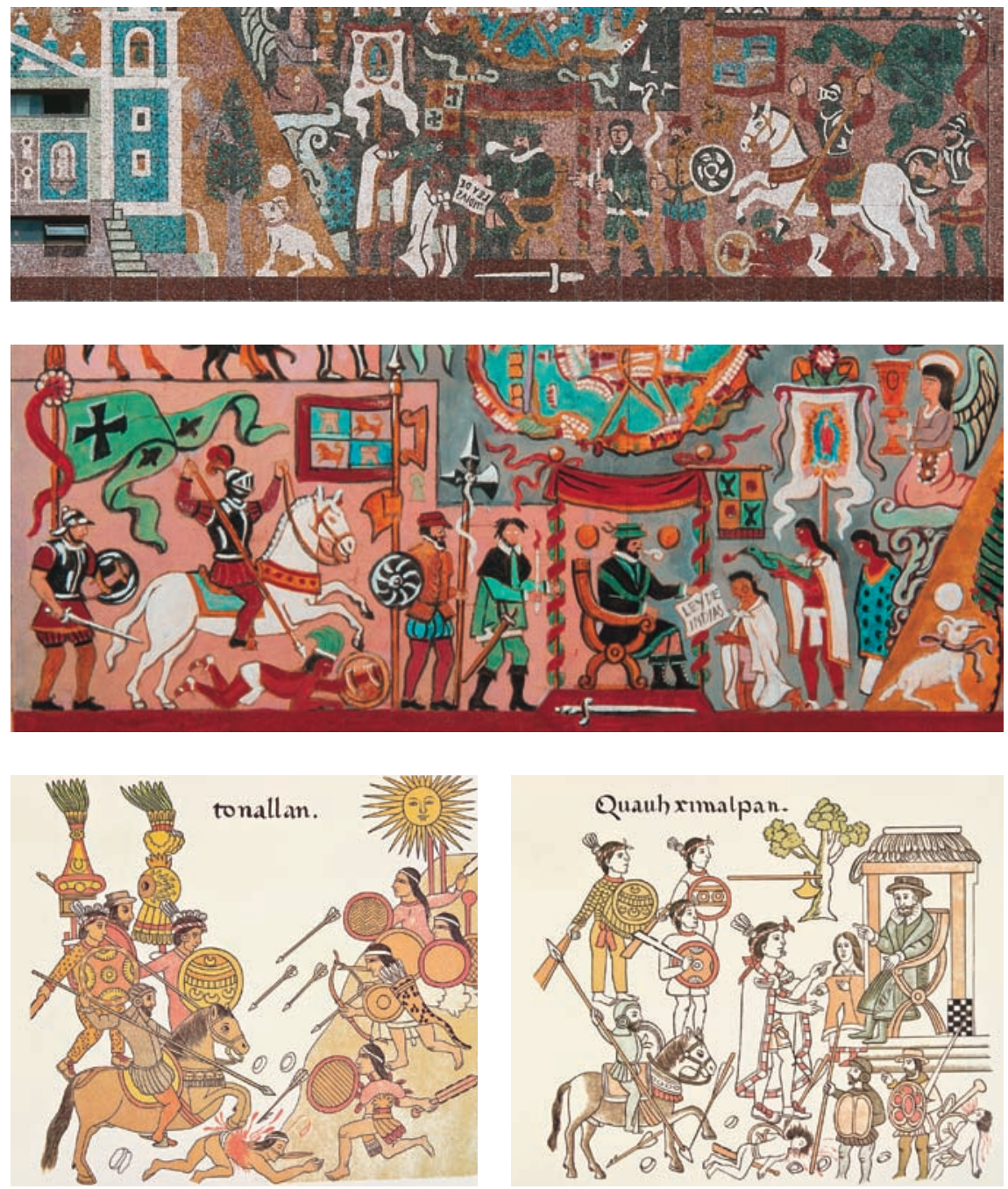

5a) Detalle del muro sur de la Biblioteca Central. Foto: Ernesto Peñaloza, 2003. Archivo Fotográfico Manuel Toussaint, IIE-unam; b) boceto del mismo. Foto: Columba Sánchez y Gerardo Vázquez; c y d) Lienzo de Tlaxcala, batalla de Tonallan, lám. 55, y "después de una batalla en Quauhixmalpan”, lám. 20. Biblioteca Nacional, UnAM. Foto: Pedro Ángeles (supra. n. I6). 
DOI: http://dx.doi.org/10.22201/iie.18703062e.2011.98.2364

I 54

RITA EDER
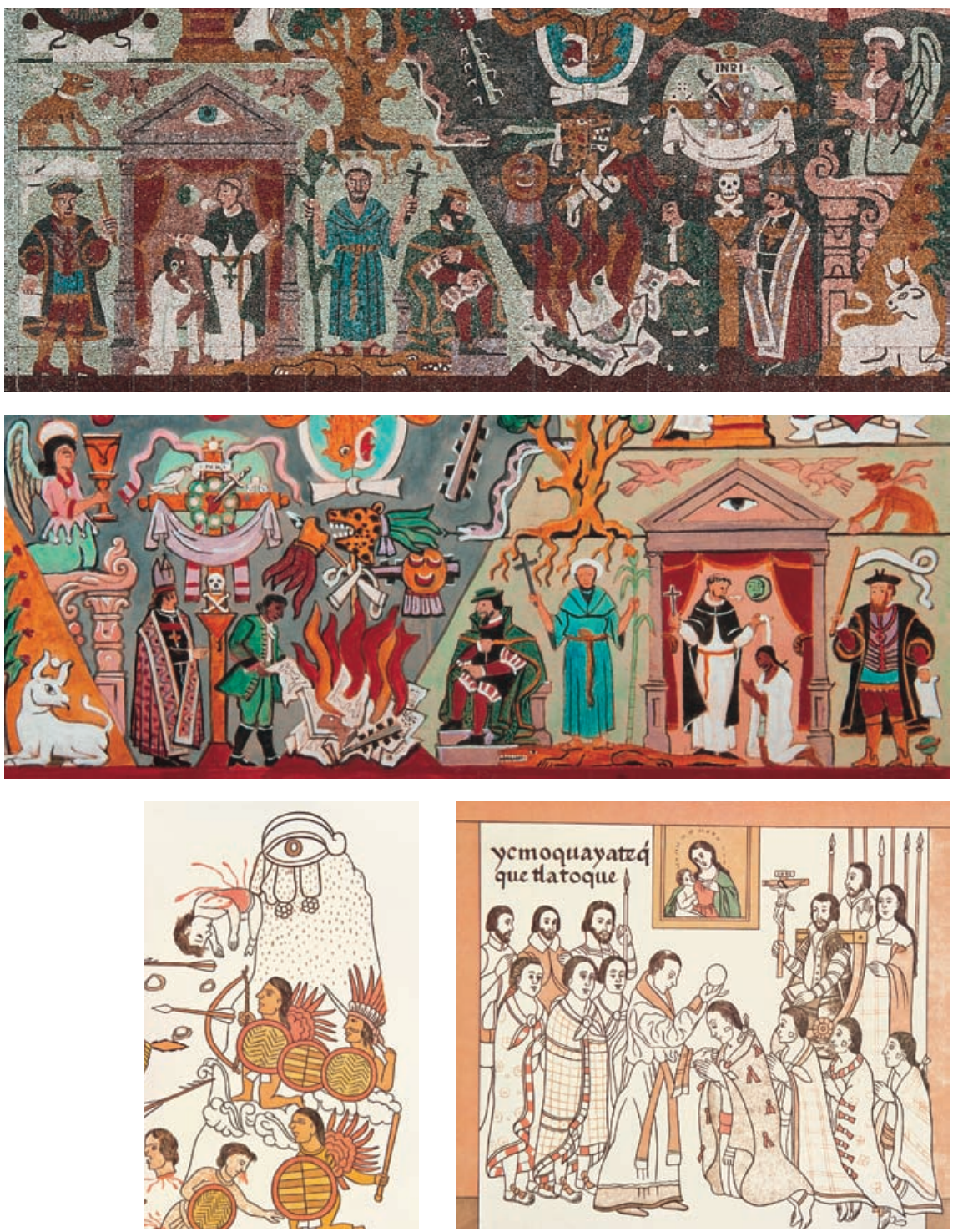

6a) Detalle del muro sur de la Biblioteca Central. Foto: Ernesto Peńaloza, 2003. Archivo Fotográfico Manuel Toussaint, IIE-Unam; b) boceto del mismo. Foto: Columba Sánchez y Gerardo Vázquez; c y d) Lienzo de Tlaxcala, batalla de Xalixco, lám. 53, y “ya se bautizaron los señores”, lám. 8. Biblioteca Nacional, unam. Foto: Pedro Ángeles (supra. n. I6). 
dos en la imagen del ojo que observa e investiga. Se establece una dicotomía entre la propuesta unívoca del mal y del bien y las visiones antagónicas del funcionamiento del universo. En éstas la profusión de ojos parece componer otro subtexto e introduce la noción de mirar y ver como el sentido que rebasa el relato histórico específico e intenta trascender como la noción fundante del encargo y dar al edificio de la Biblioteca —así como a su decoración- un carácter emblemático en tanto símbolo de sabiduría y de apertura al mundo en el encuentro de los libros. La enorme visibilidad de las dos estructuras circulares insertadas en el muro sur es destinataria de ese debate, a juzgar por las ideas que O'Gorman había declarado como misión central de su obra en Ciudad Universitaria.

\section{El conocimiento astronómico en la Nueva España y los jesuitas}

Este tipo de planisferios fueron el soporte de un debate en la Nueva España que tuvo lugar en el ambiente universitario donde circulaban las ideas y enseñanzas astronómicas. Los jesuitas, que tienen un importante protagonismo en el desarrollo de la educación en México y son ampliamente identificados con la Ilustración, dieron en principio una acogida negativa al heliocentrismo. Los trabajos del historiador de la ciencia Elías Trabulse corrigen ideas establecidas sobre la negación total del heliocentrismo en tiempos virreinales, ya que en ese tema (el astronómico) se libra, dice el autor, una de las batallas más interesantes entre modernidad y tradición ortodoxa científica y religiosa. A mediados del siglo XVIII, arribaron las ideas newtonianas a la Nueva España y gran parte de la investigación de Trabulse se basa en una revisión de bibliotecas particulares y de diversas órdenes religiosas, así como en volúmenes confiscados por la Inquisición, además del abundante intercambio de libros que llegaban a las costas mexicanas por medio de los viajeros. Trabulse señala el cultivo de la astronomía moderna mediante el arribo de libros, planes docentes, mediciones de eclipses y un deslinde de las ideas aristotélicas, las cuales dejan claro que, si bien la versión oficial es que prevaleció el geocentrismo de Tolomeo, el debate, sin embargo, fue intenso y todo hace pensar que el heliocentrismo era discutido y enseñado como un discurso paralelo para combatir el control de las ideas científicas por parte de la Iglesia. Trabulse deja en claro que la Ilustración penetró a través de los libros y las ideas y fungió como una prepara- 
DOI: http://dx.doi.org/10.22201/iie.18703062e.2011.98.2364

I 56

RITA EDER

ción hacia el movimiento de Independencia de I8Io. Quizá uno de sus trabajos más interesantes sobre astronomía moderna es el dedicado a sor Juana Inés de la Cruz y su largo poema Primero sueño, ${ }^{19}$ el cual perfila su deseo de entender el cosmos como el vuelo del alma, libre de restricciones y de acuerdo con los conocimientos de su tiempo, cercano a las ideas keplerianas:

Siendo de noche, me dormí, soñé que de una vez quería comprender todas las cosas de que el universo está hecho [...] Como una centella que se goza en su propio parecido y que se separa de la cadena corporal que embaraza o impide el vuelo del intelecto, contempla el curso irregular con que giran desigualmente las bóvedas celestes. Es como si estuvieran en la altísima cumbre de un monte más alto que el Atlas y más alto que el Olimpo, donde se deshacen las nubes y el águila no alcanza y más alto también que las pirámides de Egipto, cuyas cúspides se lanzan a una esfera de luces invisibles para desplomarse luego.

Primero sueño enuncia la idea de la expansión del universo que no se atiene a los límites tradicionales del cosmos como el mundo de Dios.

Podemos concluir del trabajo de Trabulse, así como del de otros autores como Marco Antonio Moreno Corral, ${ }^{20}$ que en realidad sí hubo penetración de las ideas modernas de la astronomía en la Nueva España, pero este proceso fue objeto de resistencia. En su estudio sobre Copérnico, Moreno Corral ha trazado la trayectoria del astrónomo polaco en México y desentraña con minuciosidad la recepción que tuvo su De revolutionibus en tierras novohispanas y el proceso polémico del cual fue objeto. ${ }^{2 \mathrm{I}}$

19. Elías Trabulse, "El hermetismo y sor Juana Inés de la Cruz", en El círculo roto. Estudios históricos sobre ciencia en México, México, Fondo de Cultura Económica/Sep8os, 1982, p. 75.

20. Marco Antonio Moreno Corral, Copérnico y el heliocentrismo en México, México, Universidad de Guanajuato, 2004.

2I. Idem. Parte central de su investigación es la localización del origen y destino de ejemplares de la obra copernicana De revolutionibus, la cual arribó por Veracruz, seguramente — dice Moreno Corral - como pedido de un astrónomo muy competente avecindado en el puerto. Con él llegó también un ejemplar de Nicolás de Cusa, quien rompió con la concepción geocéntrica clásica, al explicar los movimientos circulares del Sol y la Tierra, y rechazó la existencia de un centro cósmico y la noción de un planeta inmóvil. Un dato que llama la atención es el hecho de que en 1655 el Tribunal del Santo Oficio encarceló a Melchor Pérez de Soto, arquitecto mayor de las obras de la catedral. Se le incautó su rica biblioteca y entre los libros confiscados se encontraba el texto de Nicolás Copérnico De revolutionibus orbium coelestium, un ejemplar de la segunda edición elaborada por Henri Petraeus en Basilea en 
DOI: http://dx.doi.org/10.22201/iie.18703062e.2011.98.2364

TOLOMEO Y COPÉRNICO EN EL NUEVO MUNDO

Los jesuitas conocían sus principios, los enseñaban en la universidad novohispana; sin embargo, se referían al heliocentrismo como otro punto de vista sobre el origen del cosmos. Para ello basta examinar un documento de Francisco Xavier Clavijero, De las dificultades para aceptar la tesis heliocentrista. ${ }^{22}$ En este texto, Clavijero explica con detalle en qué consiste lo que él llama la tesis de Copérnico; después de mostrar cuán bien la conoce, concluye lo siguiente en el apartado "Dos conclusiones y sus argumentos sobre la teoría copernicana":

El sistema copernicano no puede ser defendido como tesis $[\ldots]$ I ${ }^{\circ}$. Porque $[\ldots]$ parece oponerse a las Sagradas Letras; $2^{\circ}$. Porque los jueces romanos de la fe la juzgaron absurda y herética $[\ldots] ; 3^{\circ}$. Porque $[\ldots]$ fue puesta por la Compañía de Jesús en la lista de opiniones proscritas y fue prohibida a los profesores de filosofía [...]; $4^{\circ}$. [Por la imposibilidad de que] la Tierra sea impulsada a la vez por tres movimientos diversos. El sistema copernicano no puede admitirse ni siquiera como hipótesis. ${ }^{23}$

Según dice Jean Lacouture, en el capítulo "El árbol de la ciencia" — parte de su extenso libro sobre los jesuitas-, ${ }^{24}$ hubo enormes contradicciones en la orden entre el saber científico y los principios religiosos. Muchos lamentaron el juicio de Galileo; no obstante, mediante "el recurso de la investigación sistemática lograron la autonomía progresiva de la investigación científica de las enseñanzas de la teología”. ${ }^{25}$ Cita a Athanasius Kircher, quien abrió la vía al

I566. La presencia de obras de astronomía en la biblioteca del arquitecto mayor de la catedral, formado por un grupo de intelectuales interesados en las ciencias físicas, hace pensar que en verdad estos copernicanos estuvieron fuera del orden de la Iglesia. El heliocentrismo empezó a incluirse en forma regular en los libros de ciencias físicas y matemáticas que se escribían en México a mediados del siglo xix; sin embargo, como herencia de los conflictos religiosos, muchos educadores mexicanos adoptaron una postura ambivalente respecto de las ideas copernicanas. En 1850, incluso en los libros doctos en astronomía, se discutía acerca de los diversos sistemas dando preeminencia al Almagesto de Tolomeo. Fue Gabino Barreda, hacia I867, quien destacó la importancia del estudio de la ciencia en México y defendió como tesis definitiva el heliocentrismo, con el cual habría que educar a las nuevas generaciones. El ya mencionado cuadro de Félix Parra es testimonio de un viraje radical en la enseñanza de la astronomía en México.

22. Elías Trabulse, Historia de la ciencia en México. Estudios y textos, siglo XVIII, México, Conacyt/Fondo de Cultura Económica, 1985, p. 483.

23. Francisco Xavier Clavijero, Physica particularis, Bernabé Navarro (trad.), en Trabulse, Historia..., op. cit.

24. Jean Lacouture, Jesuitas, II: Los continuadores, Barcelona, Paidós, I994.

25. Ibidem, p. 33I. 
evolucionismo al decir que ni por dentro ni por fuera la Tierra ha permanecido en el curso de los años en el estado que tenía al principio. ${ }^{26}$

Las siguientes páginas de su libro presentan el debate entre la fe y la ciencia, la astronomía sin duda fue una de las posturas más difíciles y delicadas que tuvo que enfrentar la compañía tan dedicada a la ciencia, sobre todo a las matemáticas y a la geometría. La astronomía, según Lacouture, seguirá siendo de siglo en siglo, de Curtius a Secchi, un campo de acción privilegiado de la investigación jesuita. El texto continúa seńalando a varios personajes estrellas del mundo jesuita: inventores, experimentadores multifacéticos como Calvius y Scheiner que admiraron y fueron en varios sentidos precursores de la astronomía moderna, sobre todo Scheiner, quien se adelantó a Galileo al descubrir las manchas del Sol. ${ }^{27}$

\section{Una iconografía antigua en tiempos modernos}

En la década de los años cuarenta del siglo xx, se fundaron en México instituciones que promoverían el avance de la astronomía y la física. Con la ayuda de Manuel Ávila Camacho y la Universidad de Harvard, y sin duda como parte de la política del buen vecino de Franklin Delano Roosevelt, quien aspiraba a que México le declarara la guerra al Eje, algo no ocurrido hasta mayo de 1942, Luis Enrique Erro fundó un observatorio astronómico moderno con equipo adecuado. Ya retirado, apenas pasados los 50 años, escribió en Cuadernos Americanos — quizá la revista cultural más prestigiada de la década de los cuarenta- "Las ideas básicas de la astronomía moderna". ${ }^{28}$ En parte son sus memorias de la fundación del observatorio de San Pedro Mártir en Tonantzintla, en 1942, y también hace saber al lector sobre las dificultades de trasladarse a un lugar alejado de la capital y de convencer a los científicos de que realizasen su trabajo ahí. Comenta con detalle el paisaje, las hermosas montañas visibles desde ese emplazamiento y el entorno social que rodeaba ese centro astronómico. La segunda parte está dedicada a definir qué es la astronomía moderna y, como Hubble, lo hace alrededor de una noción de un cielo grande.

\footnotetext{
26. Idem.

27. Ibidem, p. 384 .

28. Erro, op. cit.
} 
Por obra de Galileo, Copérnico y Newton quedó claro que no hay esferas celestes sino que el movimiento diurno del cielo es la rotación de la Tierra sobre su propio eje, el cielo se hizo automáticamente grande, aquellas cosas que se suponía estaban en la cara exterior de la esfera de las estrellas fijas quedaron sin un lugar en el universo [...] Aquel cielo chico, con la Tierra en el centro y alrededor de ella las diversas esferas girando más o menos simplemente tenía para ciertas cosas una ventaja indiscutible, señalaban el camino al cielo. Irse al cielo era irse para arriba, como el humo del incienso [...] Por no someterse a ese materialismo Giordano Bruno y otros perecieron en la hoguera y se fueron por esa vía al cielo. ${ }^{29}$

A lo largo de su texto sobre astronomía moderna, Erro hace alusión a las contribuciones de los jesuitas y a los desencuentros entre esta orden religiosa y la astronomía. Erro mantenía relaciones de amistad con Antonio Ruiz, Juan O’Gorman y con el mecenas de Ruiz: Valente Souza. Ruiz tenía en común con Erro, además de una amistad duradera, el haberse educado en colegio de jesuitas, lo cual pareciera que los expuso al debate de la astronomía en el que intervenían las tensiones entre ciencia y religión. Al respecto dirá Erro:

Fueron los jesuitas quienes, por no amarrar ciertas oscuras cuestiones de psicología a una ciencia física cuyo desarrollo era imprevisible, comenzaron a bogar a otros rumbos. En un principio esto les costó escarnios y persecuciones, pero a la larga les hizo adueñarse del cotarro. ${ }^{30}$

El conocimiento astronómico tuvo en México una dinámica compleja y ambivalente, como lo sugiere Erro en su apreciación sobre la contribución de los jesuitas en este campo de la ciencia y como lo ha demostrado Elías Trabulse en diversos trabajos sobre el desarrollo y la enseñanza de la astronomía durante esta etapa. ${ }^{3 \mathrm{I}}$

La alusión reiterada a los jesuitas por parte de Erro y la que asimismo reafirman otros estudiosos con relación a sus contribuciones a la astronomía es un modo de acercarse a la curiosa aparición de este tema cosmográfico en un país que en ese tiempo ya había logrado establecer un centro de investigación modélico. Planisphaerium Ptolemaicvm et Copernicavm, de Ruiz, de superficie

29. Idem.

30. Idem.

31. Trabulse, El círculo roto..., op. cit. 
lisa y transparente, pintado al temple, pareciera ser — como lo es la obra en general de este pintor - una manera de subrayar su idea de la pintura (patente en otros cuadros, como El sueño de Malinche y Verano) como un dispositivo que oculta y revela, en este caso el doble sentir y actuar frente a las formas y los mecanismos del universo de ciertos sectores de la Iglesia, en particular los jesuitas que tanto defiende Erro y a quienes adjudica ser dueños del cotarro al referirse a los descubrimientos astronómicos.

\section{Ptolomeus y Copernicus de Antonio Ruiz}

Una única fotografía encontrada en el archivo de Antonio Ruiz muestra la biblioteca-estudio de Valente Souza. El mobiliario es moderno y en el lado derecho pueden verse unas columnas forradas de madera; entre columna y columna apenas asoman unos fragmentos de los mapas comisionados a El Corcito en 1936. Cómo eran esos paneles pintados puede deducirse de algunos dibujos que Ruiz realizó para preparar los mapamundis definitivos que decorarían la biblioteca de Souza. Esto indica la vuelta del artista a los empeńos de su antiguo trabajo en el departamento de cartografía y dibujo de la Secretaría de Comunicaciones y Transportes que abandonó en 1926 y en el que trazaba mapas de carreteras y plantas arquitectónicas.

En 1949, I3 años después, Ruiz realizó el mural con el tema de Tolomeo y Copérnico bajo pedido de Souza..$^{32} \mathrm{El}$ mecenas de Antonio Ruiz era un gran aficionado a la astronomía. Padre del galerista Antonio Souza, ha sido descrito como un hombre de impecable gusto y de una gran afición por la astronomía. ${ }^{33}$ No sabemos si fue el mecenas o Ruiz quien decidió adoptar el modelo comparativo armónico en el que aún se hablaba del heliocentrismo como una hipótesis más.

Planisphaerivm Ptolemaicum et Copernicavm de El Corcito, por su visión neutral y aire decorativo, no parece anunciar los grandes debates sobre la forma y sustancia del cosmos ni los problemas que desató el heliocentrismo, cuando en ı6ı6 la Inquisición tomó en sus manos el destino del razonamiento copernicano.

32. El mural se encuentra hoy en las bodegas del Museo de Arte Moderno del Instituto Mexiquense de Cultura en Toluca, Estado de México.

33. Valente Souza, dueño de un negocio de instalaciones eléctricas, logró una situación próspera gracias a la expansión y el crecimiento de la ciudad de México en los años de posguerra, evidentes en los nuevos edificios que aparecieron en la avenida Reforma, entre la Diana Cazadora y la calle Niza, en la zona del Monumento a la Independencia. Conversación con Pedro Friedeberg, 7 de septiembre de 2008. 
Algo más hay que advertir en la imagen de Antonio Ruiz: las tradiciones visuales del quehacer cartográfico son muy variadas. Si bien su Tolomeo es coherente con la tradición de la imagen geocentrista, su mirada sobre la centralidad del Sol disminuye la importancia de los planetas y el tamańo de la Tierra para dejar el rostro del Sol con cara humana, como aparece en el medievo e incluso hasta bien entrado el siglo xvir. El Sol y sus manchas, según las observaciones telescópicas de Galileo, no habían cambiado la cartografía cosmográfica de la época. ${ }^{34}$ El círculo que inscribe al Sol en el centro forma parte de una cosmografía aún fiel a diversas convenciones iconográficas medievales, como representar el Sol con cara humana, con ojos y boca y los rayos que adornan su redonda cabeza como si en parte fueran cabello y en parte luz. El último círculo en el esquema de esta convención redonda de representación coloca un círculo zodiacal también de tradición visual medieval que, sin embargo, fue utilizado en algunos mapas del siglo Xvin dedicados a Copérnico. Los límites visuales que establece el zodiaco muestran una imagen que aún no absorbe las consecuencias del razonamiento copernicano, del cual se deduce que el universo no tiene límites, que está en expansión y que además existen otros sistemas solares. ${ }^{35}$ La técnica al temple acentúa el parecido con el preciosismo de las imágenes del cosmos en el medievo; no busca una descripción científica pero, en cambio, glorifica el universo como un espejo del alma y las concepciones religiosas sobre el origen de la vida. Así, la visión plana inscrita en el mural de El Corcito es indicativa de una mirada no conflictiva sobre la convivencia de los dos sistemas. Luis Enrique Erro, buen amigo de Ruiz y de Souza, aprobó con entusiasmo la realización de la encomienda, como se evidencia en una carta de carácter personal en la que lo felicita y hace referencia a la infancia que los tres pasaron juntos. ${ }^{36}$

34. Horst Bredekamp, Galilei der Künstler. Die Zeichnung, der Mond, die Sonne, Berlín, Akademie-Verlag, 2007. Galileo inició observaciones sobre el Sol entre septiembre de I6I I y agosto de I6I2. Estas observaciones tienen el carácter de un diario del Sol, ya que fueron realizadas día a día y dibujadas, lo que permite observar que las manchas cambian de lugar y de forma. El cuerpo del cielo que Galileo observaba con su telescopio se encontraba entre la Luna y Mercurio, y en el periodo marcado hizo 450 observaciones. El primer investigador del Sol que hizo observaciones y dibujos fue Christoph Scheiner (como se mencionó en Lacouture previamente citado), maestro de matemáticas y hebreo, en el colegio jesuítico de Ingolstadt.

35. Manuel Peimbert, El universo y el razonamiento copernicano, México, Universidad Nacional Autónoma de México, 1998.

36. La carta firmada por Erro y fechada el 8 de junio de 1949 está escrita en papel membretado del Observatorio Astrofísico Nacional y dice: "Querido Antonio: Recibí oportunamente 
En el caso de Ruiz, además de existir información sobre su pertenencia a una congregación religiosa, ${ }^{37}$ manifiesta su controversia con el uso emblemático de ciertos signos que utilizó el nacionalismo mexicano y su inconformidad con el lugar de la religión en tiempos posrevolucionarios. En México 1935, obra pintada ese mismo año, intenta representar la diversidad social del México de esa década. Quizá el conjunto pictórico más elocuente de su pequeño cuadro para nuestro argumento es el ubicado en el lado derecho inferior donde aparecen Garrido Canabal y Narciso Bassols, dos personalidades conocidas por su extrema militancia anticlerical, aunque muy diferentes entre sí, más otros personajes con expresiones feroces: rostros y lenguaje corporal agresivo y amenazante; cerca de ellos, el Cristo pisoteado y fragmentado alude a la quema de imágenes y esculturas en madera que se practicó en el tiempo en que Garrido fue gobernador de Tabasco y cuya persecución religiosa inspiró el libro Caminos sin ley y la novela El poder y la gloria, ambos de Graham Greene. Planisphaerivm Ptolemaicum et Copernicavm es quizá una manera de oponerse, en clave simbólica, a la visión liberal de la historia de México presente en los muros pintados que evidenciaban un fuerte anticlericalismo sin hacer alusión a otras características de la Iglesia, como la contribución silenciada, pero existente, de los jesuitas a la ciencia, en general, y a la astronomía, en particular.

\section{La revolución copernicana como melancolía}

En cuanto a Juan O'Gorman, también amigo de Erro (construyó para él su casa en 1932) y desde luego muy cercano a Ruiz, el tema astronómico ciertamente complicó su intención inicial de basarse en los códices y de hacer una propuesta mexicanista al implantar aquellos dos círculos inspirados en el pequeño mural de su admirado maestro y amigo. Si bien, como señalamos antes, el muro sur de O’Gorman instala el conflicto entre ciencia y religión, habría que buscar la clave mayor en la polaridad bien/mal en la que el arquitecto y pintor insiste y cuya significación invierte y desplaza, y con ello intro-

la fotografía del mural que pintaste sobre asuntos astronómicos. Me figuro que fue pintado para Valente Souza, nuestro antiguo compañero. Ya todos nosotros somos bastante antiguos. El mural está muy bien y se advierte que está ejecutado con el dominio que te es característico. No sé si te mantienes en contacto con Valente; si así fuera te agradecería mucho que le dijeras de mi parte que me causaría placer si me autorizara a ir contigo a ver el mural”. Archivo de Antonio Ruiz. Cortesía de Luisa Barrios.

37. Entrevista con Luisa Barrios, nieta del pintor y custodia de su archivo. 
duce la sensación de malestar e incertidumbre, así como cierta melancolía, quizá no ante el avance científico, pero sí ante el emblema copernicano como signo de la revolución, inscrita en el título de su tratado (De revolutionibus). En un momento en que el discurso sobre la revolución se había oficializado, posiblemente la idea moderna de evolución, progreso, avance o cambio era puesta en duda por el arquitecto, ${ }^{38}$ y es esta duda que expresa en el muro sur, la cual guarda afinidades con una tensión y una visión crítica distintas respecto del infinito y el tamaño y forma del universo surgidos a finales del siglo xx, desde el humanismo frente a la ciencia, para presentar los estragos del descubrimiento copernicano sobre el antropocentrismo.

\section{El cosmos y el fin del milenio}

Cosmos, una exhibición curada por Jean Clair en 2000, tuvo como intención central marcar el debate entre el espacio como dimensión física y filosófica y las artes visuales. La crisis moderna ante nuevas nociones del espacio fue uno de los puntos focales. Varios ensayos del catálogo manifestaban como tema de reflexión el paso de un universo abarcable y armónico a la desprotección y desajuste que surge durante el romanticismo ante la mayor divulgación del conocimiento científico sobre la estructura del universo.

El conocimiento espacial del siglo xx tuvo otras consecuencias, como el entendimiento de diversos mundos en constante gravitación. Esto provocó una enorme cantidad de literatura de ciencia ficción sobre esferas habitadas por extraterrestres y la esperanza de un mundo nuevo en que los humanos pudieran conectarse de un planeta a otro. Vinculados a ello están los diversos movimientos de vanguardia que se apasionaron por las formas de los astros y experimentaron con el espacio y la luz desde diversas perspectivas esotéricas y científicas. Finalmente está la fotografía del espacio y su lugar en el arte contemporáneo que reflexiona sobre la incertidumbre del cosmos desde las nociones de la forma y la expansión del universo sustentadas en observaciones astronómicas y nuevas tecnologías fotográficas. ${ }^{39}$

38. La tendencia de una crítica velada a la Revolución desde mediados de los años treinta se aprecia en la pintura de caballete de pequeño formato; entre algunas obras con ese tema destacan El sueño de Malinche de Ruiz, las tehuanas — que parecen congeladas- de Montenegro y aun una obra menos conocida de Frida Kahlo, El guerrero, de 1938.

39. Jean Clair, "De Humboldt a Hubble", en Cosmos, op. cit., p. I4. En 1999 Jean Clair 
DOI: http://dx.doi.org/10.22201/iie.18703062e.2011.98.2364

I 64

RITA EDER

\section{El presente y la revaloración de la esfera}

Entre 1998 y 2004, Peter Sloterdijk escribió y publicó una extensa obra en tres volúmenes que lleva por título Esferas..$^{\circ}$ Escrita bajo el signo del platonismo, el universo del geómetra y la significación de las formas ideales, Sloterdijk sugiere que la forma redonda del mundo de antes permitió que Occidente, durante siglos, se sintiera en su centro. El cambio drástico sobrevino con el Siglo de las Luces, al cual Sloterdijk se refiere con ironía y entre comillas, postura que se acentúa en su crítica de la modernidad y en el escepticismo que le produce la noción de progreso.

fue convocado por el Museo de Bellas Artes de Montreal en calidad de curador de la muestra Cosmos. A él se debe el primer artículo del catálogo bajo el título "De Humboldt a Hubble”, el cual inicia la reflexión comparativa entre el mundo de antes, que provocaba plenitud y alegría, y el moderno, que se ha convertido en "grandeza excesiva" incontrolable y que lleva consigo la amenaza de la aniquilación. Tanto los románticos alemanes como los franceses (el caso concreto de Victor Hugo), experimentaron esa sensación de terror como horror sagrado o lo que se conoce como lo ominoso. Humboldt, de acuerdo con Clair, es quien da la última gran vuelta al mundo con la idea de que su genio y sus conocimientos diversos contenían la capacidad de abarcarlo todo. El terror da paso a la imaginación: ¿cómo encontrar y comunicarse con esos otros mundos que están en el espacio infinito? Stéphane Deligeorges continúa con el dilema abierto por Clair en su contribución "La escala del universo. De lo finito al infinito", en Cosmos, op. cit., p. 39. El autor se interesa por el Timeo de Platón, en el que el filósofo se pregunta: ¿̨uál es la historia del mundo?, ¿cómo se originó? Su respuesta, una imagen detenida y coherente del universo físico; un mundo único, esférico, circular, eterno. Para Aristóteles, la esfera terrestre es inmóvil y de pequeñas dimensiones, se encuentra suspendida en el centro geométrico de otra esfera mucho más vasta, en rotación y que contiene las estrellas; su movimiento circular es la perfección divina. Frente a esta concepción del universo como finito y cerrado, perviviendo por más de 2000 años, están aquellas que concibieron el mundo como abierto e infinito; como las de Epicuro y Giordano Bruno, Kant y Hershel, entre otros.

En su Teoría del cielo (I755), Kant afirma que la materia del mundo se encuentra en un estado de dispersión general que consiste en un caos perfecto. William Hershel perfeccionó el telescopio y pudo así observar la bóveda celeste y encontrar nebulosas y grupos de estrellas. Edwin Hubble empleó un telescopio que permitía mucho mayor conocimiento. Véase Bárbara Larson, "La nueva astronomía y la expansión del cosmos”, en Cosmos, op. cit., p. I 5 I. El globo despertó nuevas ideas sobre el ojo y la mirada; una obra notable en ese sentido es la fantástica combinación de un globo y un ojo ideada por el simbolista Odilon Redon. Larson habla extensamente sobre las hipótesis y los relatos surgidos en el siglo XIX en torno de la vida extraterrestre y el gran debate que suscitó la posibilidad de mudarse de planeta y así tener una vida mejor. Por ejemplo Joseph Péladan y su novela El vicio supremo, en la cual se habla de la vida astral que habita al ser vivo y al morir rompe el cordón que los une y se fuga hacia las estrellas para alcanzar otra concepción de eternidad.

40. Peter Sloterdijk, Esferas, 3 vols., Madrid, Siruela, 2004. 
Esferas esgrime en principio que la vida es un asunto de morfología, una geometría esférica de la cual brota lo humano en forma de globos itinerantes o fijos, más redondos aún de lo que pueden ser dibujados. Al hablar de esferas, círculos y bolas, acompaña sus textos con un extenso inventario de imágenes de notable atractivo estético en el cual destacan panópticos y cúpulas, discos solares y dibujos del universo. En ese largo recorrido que aborda la presencia de estas formas en diversas civilizaciones y periodos, un tema ineludible es la revolución copernicana. En un anticlímax frente al creciente y cambiante avance de la ciencia en el conocimiento del cosmos, Sloterdijk califica los fundamentos de la cosmografía moderna como el umbral de las decepciones.

Es esta revolución — dice el autor de Crítica de la razón cínica- la que ha hecho perder a los seres humanos que habitan Occidente su medio cosmológico y les produce descentramientos progresivos dada la hostilidad y el frío de una expansión ilimitada y desconocida del universo. Los hombres han perdido la ilusión de estar en el centro del cosmos. ${ }^{4}$

El filósofo alemán concibe esta sensación como un dilema histórico entre el progreso de la ciencia y la pérdida del domicilio del hombre. Ese dilema lo pone en boca de Kepler, quien avanzó sobre las propuestas de Copérnico e introdujo la comprobación matemática del movimiento giratorio elíptico de los planetas. Paralelamente, Kepler expresó sus temores sobre los sentimientos que produce en el hombre el conocimiento del movimiento del universo y encuentra que hay un terror secreto que responde a la pérdida de un lugar fijo, equivalente a la pérdida del techo del hombre que lo arroja a la intemperie.

En esta enciclopedia de las esferas, Sloterdijk dedica el primer volumen (1998) de su trilogía a entidades microesféricas, que llevan el nombre de bolas y constituyen las formas íntimas del ser en forma redondeada; el origen de la vida tiene esa forma y ese universo es líquido y aurático y flota en su texto la bolsa del líquido amniótico. El universo histórico-político se proyecta en forma de esfera, de disco y de círculo al servicio de la teología con sus fastuosas cúpulas, sus ciudades celestes, sus heliópolis y sus teatros anatómicos. El autor repara en las diferencias del significado del cosmos entre la antigua Europa y los teólogos judeo-greco-cristianos y afirma que los acuerdos entre las religiones residen en las concepciones morfológicas, es decir, en las esferas, como únicas e infinita- 
mente perfectas. En otras palabras, el puente entre una y otra civilización es la forma redonda del universo. La historia de las ideas de los últimos 200 años — dice el autor- entabla una disputa por la sucesión hereditaria del centro en Occidente y carga la herencia de la modernidad como un proceso de descentramientos y el consecuente sentimiento de dislocación y pérdida de equilibrio.

La catástrofe de las imágenes circulares o del mundo redondo completa la trilogía. Ya el círculo y el panóptico no son posibles. La modernidad es una revolución de la forma y la crítica conservadora habla del mundo moderno como la pérdida del círculo de Dios. La globalización puede pensarse como esferas sin redondez. La imagen del mundo de hoy es la espuma: es la teoría de lo amorfo que, espectacular y efímero, navega sobre corrientes inestables e introduce una práctica plural y transversal de la razón.

En el ya mencionado artículo de Erro hay imágenes de nebulosas que parecen espuma y son totalmente amorfas. Al fotografiar los astros a muy larga distancia - algo que ya permitían instrumentos de los años treinta y cuarenta-, las estrellas y los astros se difuminan hasta convertirse en círculos cuarteados y tendientes a perder la forma circular. Esto lleva a reconsiderar la centralidad, pues al comprobarse la rotación de los cuerpos celestes sobre sí mismos dislocan toda idea de centro. El rey Sol en el centro, desde la perspectiva de la astronomía moderna, es una estrella que da luz en abundancia; sin embargo, es una estrella común y corriente dentro de la vastedad del universo. El Sol y la Tierra forman parte de una galaxia, es decir, de una isla de estrellas; al admitir que no tienen científicamente estatus de centralidad, se deriva que el hombre no ocupa un lugar privilegiado en el universo. ${ }^{42}$

La situación del conocimiento del universo en la época y el énfasis sobre la correlación entre distancia y forma nebulosa hacen pensar que la noción de Sloterdijk de la forma contemporánea como espuma en realidad podría venir de las imágenes fotográficas de las estrellas que entre más lejos se encuentran son más afines al concepto de lo informe, como esa reafirmación de pérdida del centro.

La perspectiva que tenía Erro de la astronomía como física mostraba optimismo frente a la ciencia que tiene su equivalente en el mural de Ruiz y su paleta transparente. El caso de O'Gorman es diferente: pareciera que esa iconografía que implica el avance de la ciencia tiene sus encuentros con las Esferas de Sloterdijk. Juan O'Gorman ya había expresado un sentimiento de melancolía en varias obras de caballete de los años cuarenta, como Consumatum est 


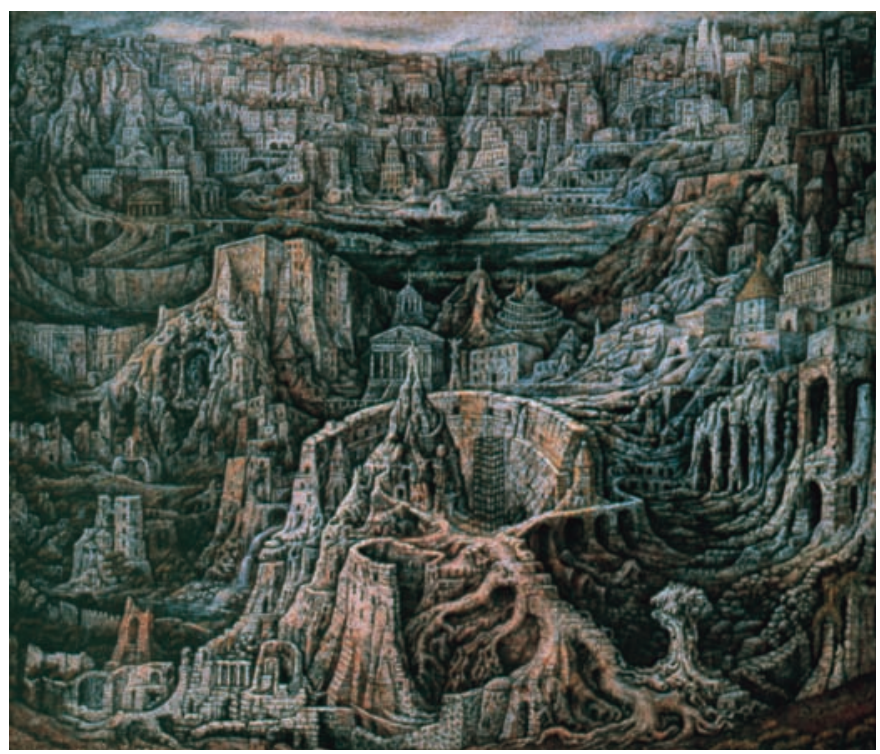

7. Juan O’Gorman, De unas ruinas nacen otras ruinas, I949, témpera al huevo sobre masonite de yeso, 4I.3 $\times 48.9 \mathrm{~cm}$. Archivo Fotográfico Manuel Toussaint, IIE-UnAm. D.R. CJuan O'Gorman/somaAp/ MÉXICO/2OII.

(1945) o De unas ruinas nacen otras ruinas (fig. 7), y en otras obras más de inspiración parecida que continuó pintando a lo largo de su vida; en varios casos sugieren la pérdida de límites espaciales y la materia como masa amorfa que por más que la sustenten estructuras arquitectónicas de diversos estilos y épocas introduce en estas pinturas paisajes distópicos en los que la naturaleza se hace viscosa e informe. Quizá sus lecturas de Cuvier ${ }^{43}$ le hicieron mirar a la naturaleza como constituida por células malignas devorándose a sí mismas. Su trabajo de caballete, tan disímbolo de su obra mural, es una crítica de la modernidad que muestra la pérdida de coordenadas espaciales conocidas. Los paisajes críticos de O'Gorman aparecen sobre todo en tiempos de guerra e incertidumbre frente al futuro.

43. Roberto Vallarino, "Evocación de O'Gorman. Semblanza en cinco tiempos”, en op. cit., p. 98. Esta aseveración de las lecturas que O’Gorman hacía de Cuvier se debe a Alejandro von Waberer, sobrino de Juan O’Gorman. 
Como imagen, el muro sur se construye por medio de dos grandes círculos que presentan modelos comparativos del universo y su impulso dinámico como emblema de la modernidad en dos sentidos. Nace una nueva formación cultural producto de la dominación y el conflicto colonial entre dos maneras de ser y representar, lo cual explica la combinación de la disputa por la forma y el funcionamiento del universo al lado de imágenes de guerra de la Conquista y el poder sobre lo indígena. Hay varios vocabularios visuales que se confrontan y contrastan. Los rostros idealizados de los conquistadores tal cual aparecen en el Lienzo de Tlaxcala, con la violencia del fuego, la imagen del diablo y la sumisión de Malinche (figs. 8a-d). En cierto sentido, el relato (impreso en enormes planos que por su forma intentan ser un símil de un gigantesco códice) está dividido en tres con el intento de contener a través de la forma (rectángulo y círculo) su contenido simbólico.

El muro sur hace pensar en cómo contraponer la historia nacional o Representación histórica de la cultura con la imagen de cosmos. La imagen se mueve en dos planos: el de la territorialidad (conquista) y el de la delimitación latente del universo conocido. Latente en el sentido en que la representación del modelo copernicano que utiliza O'Gorman — parecido al de Ruiz- está circunscrito en forma circular por el zodiaco en el que la forma de los signos proviene también del Lienzo de Tlaxcala (intentando fundir nuevamente dos concepciones distintas de imágenes) (figs. 9a-f). De tal manera, se pliega a la forma perfecta del círculo y el infinito existe en potencia; el infinito es "lo sin territorio" y la adopción de tal estrategia simbólica por parte del pintor adquiere sentido si conjugamos lo circular contenido con la idea de lo ilimitado en sus trabajos de caballete de la época en que presenta lo desbordado como catástrofe: por un lado dibuja en forma nítida y didáctica y por otro descree de lo apolíneo en sus obras de caballete. Quizá habría que recordar su Autorretrato de I950 (fig. Io), un ejercicio de dominio de la perspectiva que contiene sus varios oficios y personalidades y cuyo punto focal es activar por medios visuales el proceso de pensar el género del autorretrato como una presentación de sí mismo en tanto personalidad múltiple y dividida. Esta pintura abunda en detalles iconográficos modernos y deja para el espectador signos para desentrañar sus significados como una pintura flamenca del siglo Xv, unificada la composición por la mano que pinta. En el lado izquierdo del cuadro, O'Gorman se presenta a sí mismo como arquitecto con la escuadra en la mano y un pequeńo diablo sobre su elegante saco de tweed, un diablo con alas de ángel y con la vírgula que sale de la boca del diablillo que lleva un pincel en la mano, signo 

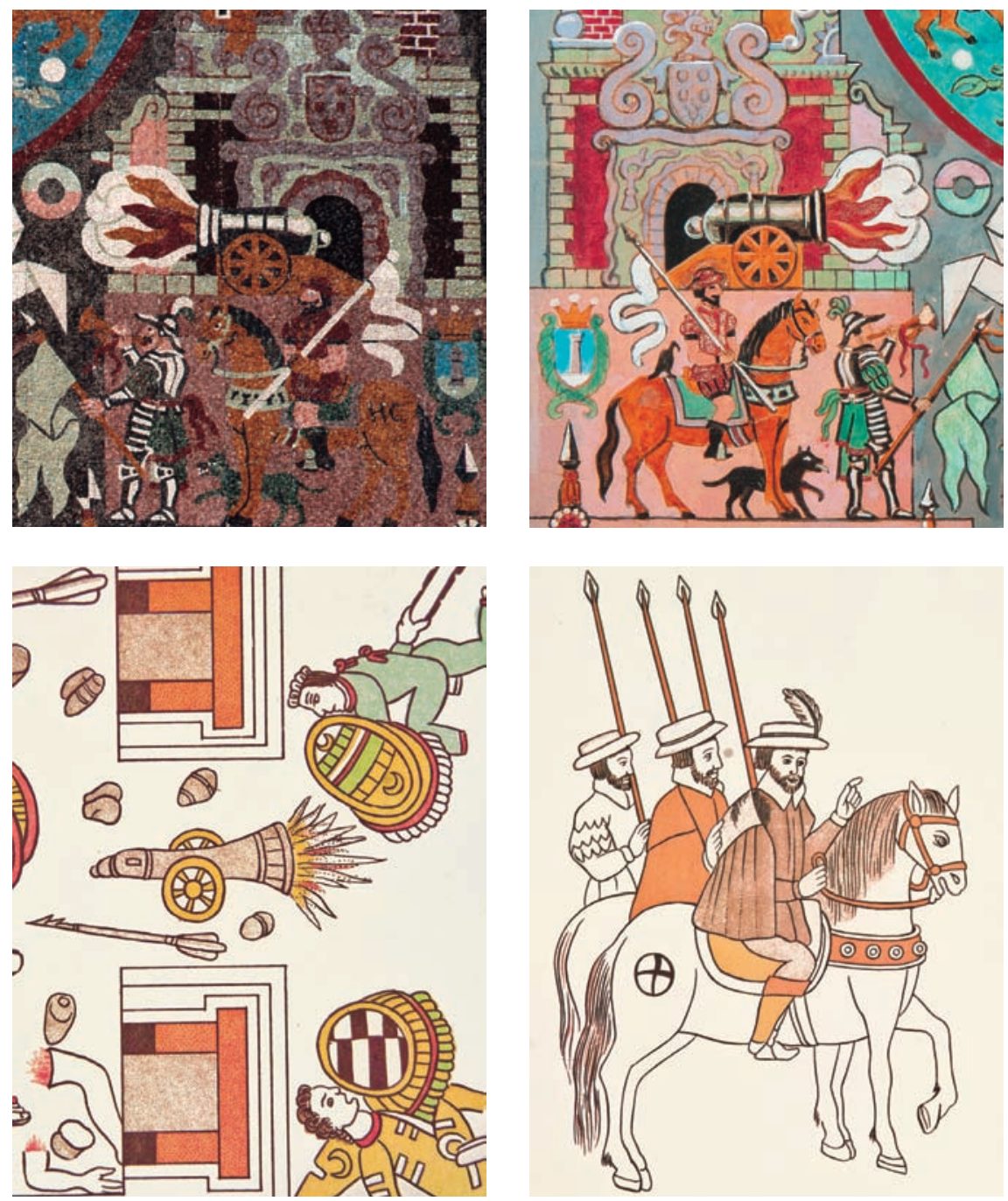

8a) Detalle del muro sur de la Biblioteca Central. Foto: Ernesto Peńaloza, 2003. Archivo Fotográfico Manuel Toussaint, IIE-UnAM; b) boceto del mismo. Foto: Gerardo Vázquez; c y d) detalles del Lienzo de Tlaxcala, "ya los habían encerrado en la casa con guerra. Sitio después de la matanza del Templo Mayor", lám. I4 y "ya fueron a la costa a prender a Narváez”, lám. I2. Biblioteca Nacional, unam. Foto: Pedro Ángeles (supra, n. I6). 

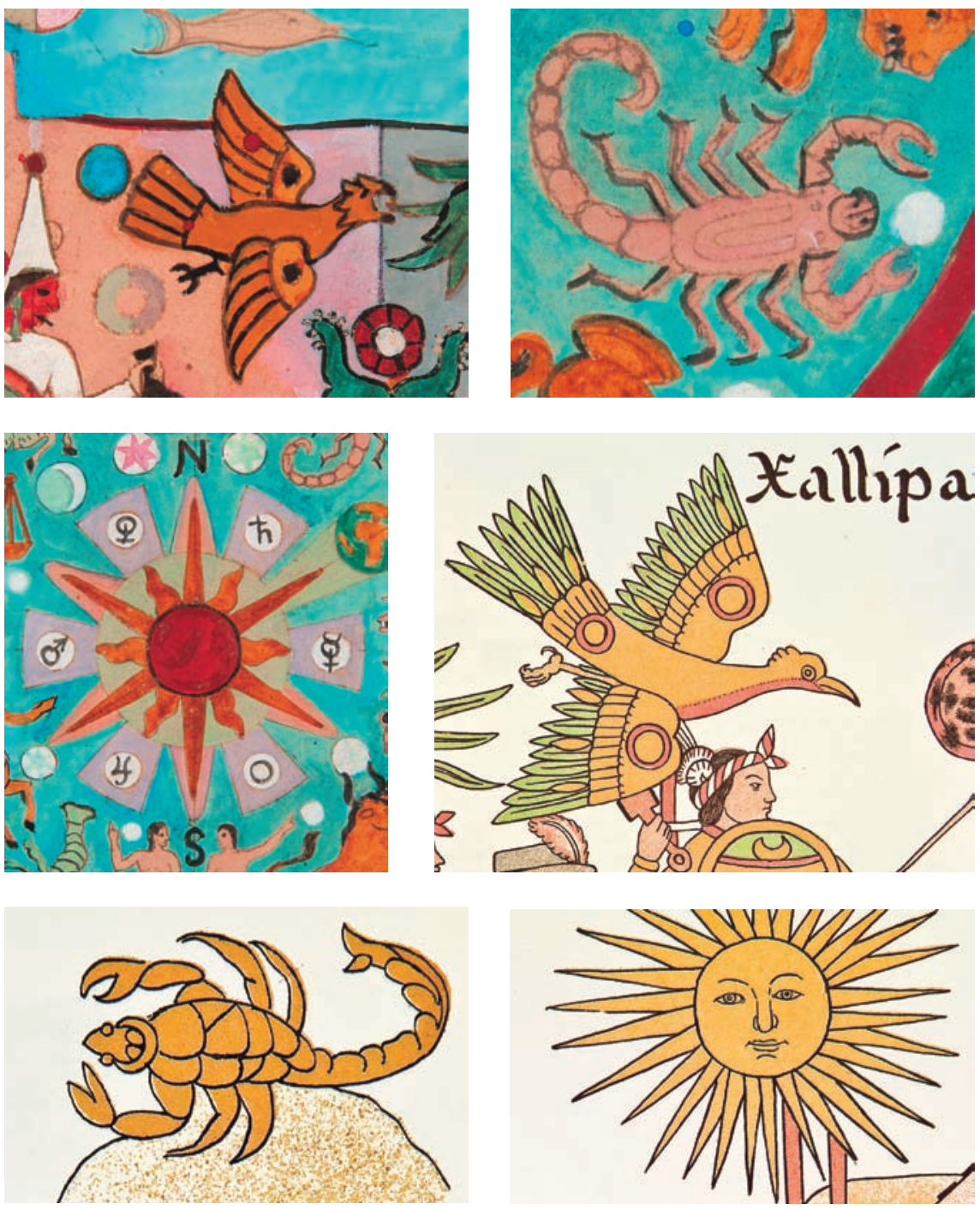

9a, b y c) Detalles del boceto para el mural de la Biblioteca Central y d, e y f) detalles del Lienzo de Tlaxcala: batalla de Xallipatlahuayan, lám. 63, batalla de Colotlan, lám. 70 y batalla de Tonallan, lám. 55. Biblioteca Nacional, unAm. Foto: Pedro Ángeles (supra, n. I6). 
DOI: http://dx.doi.org/10.22201/iie.18703062e.2011.98.2364

TOLOMEO Y COPÉRNICO EN EL NUEVO MUNDO

prehispánico del tlacuilo; unos centímentros arriba, rodeando al diablillo, hay una inscripción que dice "Esquizofrenia".

Es bien sabido que entre el historiador Edmundo O'Gorman y su hermano Juan había serias discrepancias ideológicas y de otra índole, ya que ambos transitaban - por supuesto en forma diferente- entre la historia, la pintura y la reflexión sobre la estética. Sin embargo, hay algunas afinidades de pensamiento que creo encontrar a partir del ensayo de Edmundo, "Coatlicue o de la monstruosidad", escrito en 1940, ${ }^{44}$ cuando se empieza realmente a reflexionar desde la estética alrededor del arte prehispánico. Éste es un ensayo erudito e historiográfico sobre las percepciones y la recepción de la singular diosa azteca, punto focal de un conflicto religioso. El historiador borda sobre sus cualidades estéticas y recurre al Nacimiento de la tragedia de Nietzsche que pone en valor lo dionisiaco como dispositivo para la revaloración de las normas y valores predominantes. O'Gorman fustiga la hipocresía de Occidente en forma diferente a Bataille, pero con la intención similar de apuntar el tema nietzscheano de una doble moral, ${ }^{45}$ e incorpora la estética de Coatlicue en cuanto portentosa monstruosidad opuesta radicalmente a lo apolíneo. El ensayo crítico de Edmundo en torno a la división sobre lo bello y lo feo o lo monstruoso es la contraparte de la elaboración del bien y el mal de Juan, cuya dislocación resulta un ejercicio dialéctico y una introspección respecto de lo que llama esquizofrenia en su formación cultural. Hoy sabemos mucho más de esta enfermedad en términos de sus múltiples estragos más allá de la idea de una personalidad dividida, pero quizá en 1950 fue una manera de expresar la división y perplejidad ante la totalidad a la que aspiraba como creador de una diversidad cultural y religiosa nacida de la violencia y el desencuentro. El Autorretrato tiene un aire trágico por la expresión de los rostros de O'Gorman como pintor y arquitec-

44. Edmundo O’Gorman, "Coatlicue o de la monstruosidad", en Martha Fernández y Louise Noelle Gras, Sesenta años del Instituto de Investigaciones Estéticas, México, Universidad Nacional Autónoma de México, 1996.

45. Georges Bataille, autor de L'Amerique disparue (1928), hace un reconocimiento del sacrificio y el desmembramiento del cuerpo como una propuesta para renovar la estética occidental. En su Diccionario crítico inscrito en Documents - la revista fundada por él junto con Carl Einstein - es autor de varias entradas, entre ellas abattoir (matadero), acompañada de fotos de un matadero en París cuyo derrame de sangre es más violento que la práctica sacrificial y el desmembramiento. Una forma de apuntar a la hipocresía de Occidente ante las prácticas rituales de los así llamados pueblos primitivos. Véase Dawn Ades y Simon Baker, Undercover Surrealism: Georges Bataille and Documents, Londres/Cambridge, Hayward Gallery/Mit Press, 2003. 
DOI: http://dx.doi.org/10.22201/iie.18703062e.2011.98.2364

I 72

RITA EDER

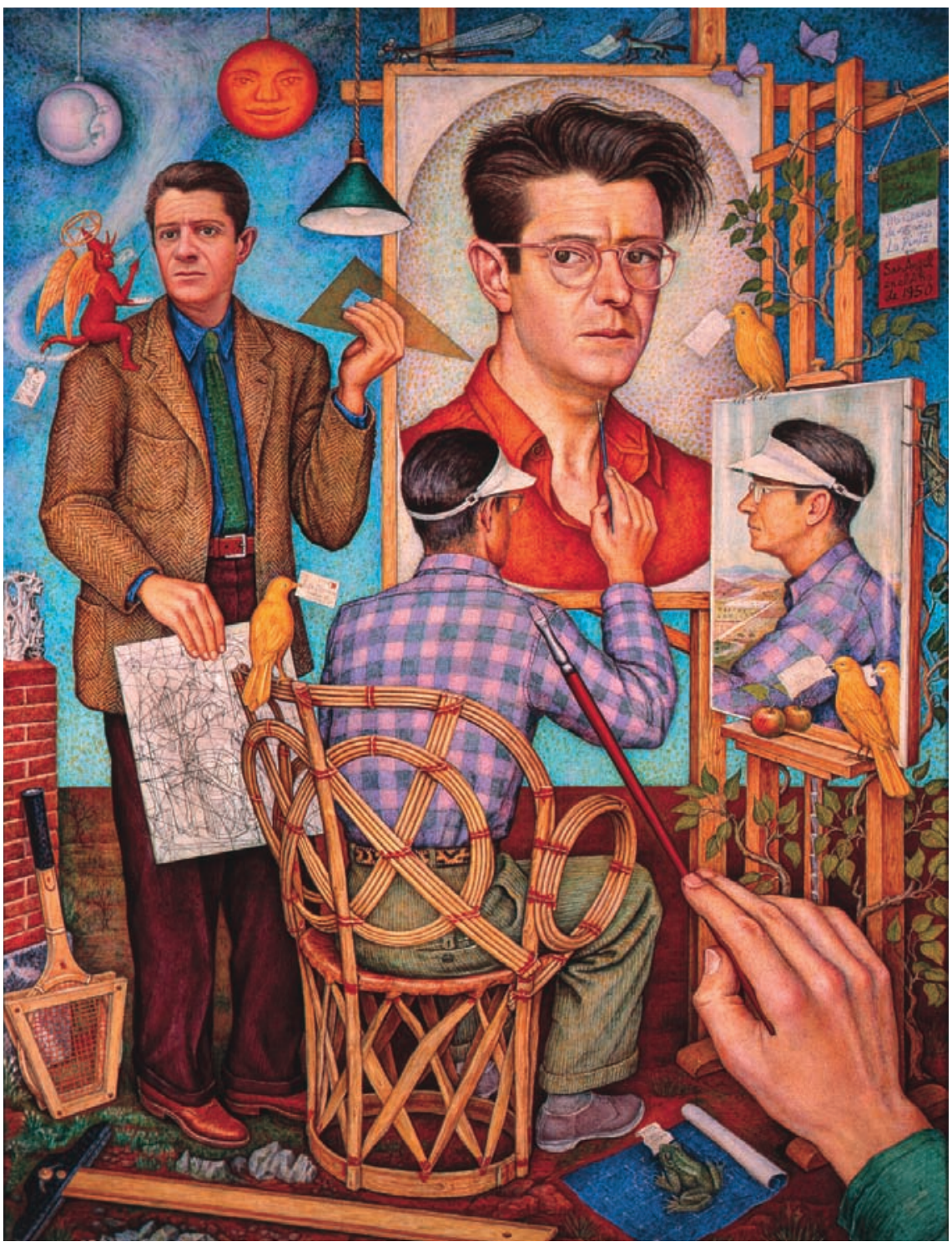

Io. Juan O’Gorman, Autorretrato múltiple, I950, Museo de Arte Moderno. Archivo

Fotográfico Manuel Toussaint, IIE-UnAM. D.R. CJuan O'Gorman/somaAp/MÉXICO/20I I. 
to y su incertidumbre de poder lograr ser el artista total, como tanto lo había discutido con Diego Rivera.

Puedo concluir que, en el plan total de la decoración de la Biblioteca, O'Gorman se separa de la enorme influencia que Rivera ejerció sobre él y en particular se aparta del evolucionismo optimista de la historia y de la naturaleza. Pone en cuestión precisamente en el muro sur los valores del bien y el mal como un recurso crítico que alude a sus equívocos y relativismos. Por razones de diversa índole, como ya se ha mencionado, el plan decorativo de la Biblioteca Central anuló la porción del futuro de la humanidad y el de la física para colocar el escudo universitario; quizá esto fue una imposición que no le vino mal a O'Gorman y su mirada escéptica sobre la naturaleza, el hombre y su incertidumbre frente al devenir y quizá también sobre el efecto de las revoluciones. \$̊

N.B. Agradezco a mis colegas del Instituto de Investigaciones Estéticas, Jaime Cuadriello, Jesús Galindo y Fausto Ramírez, sus invaluables sugerencias y lecturas críticas para la realización de este trabajo.

* Artículo recibido el 8 de mayo de 20 I; aceptado el I8 de mayo de 20 I. 